\title{
Lyssaviruses and rabies: current conundrums, concerns,
}

\section{contradictions and controversies [version 1; peer review: 2}

\section{approved]}

\author{
Charles Rupprecht ${ }^{1}$, Ivan Kuzmin², Francois Meslin³ \\ ${ }^{1}$ Wistar Institute, Philadelphia, PA, 19104, USA \\ 2University of Texas Medical Branch at Galveston, Galveston, TX, 77555, USA \\ ${ }^{3}$ DVM, former Team Leader, Neglected Zoonotic Diseases, WHO Headquarters, Geneva, Switzerland
}

V1 First published: 23 Feb 2017, 6(F1000 Faculty Rev):184

https://doi.org/10.12688/f1000research.10416.1

Latest published: 23 Feb 2017, 6(F1000 Faculty Rev):184

https://doi.org/10.12688/f1000research.10416.1

\section{Open Peer Review}

Approval Status

\section{Abstract}

Lyssaviruses are bullet-shaped, single-stranded, negative-sense RNA viruses and the causative agents of the ancient zoonosis rabies. Africa is the likely home to the ancestors of taxa residing within the Genus Lyssavirus, Family Rhabdoviridae. Diverse lyssaviruses are envisioned as co-evolving with bats, as the ultimate reservoirs, over seemingly millions of years. In terms of relative distribution, overt abundance, and resulting progeny, rabies virus is the most successful lyssavirus species today, but for unknown reasons. All mammals are believed to be susceptible to rabies virus infection. Besides reservoirs among the Chiroptera, meso-carnivores also serve as major historical hosts and are represented among the canids, raccoons, skunks, mongooses, and ferret badgers. Perpetuating as a disease of nature with the mammalian central nervous system as niche, host breadth alone precludes any candidacy for true eradication. Despite having the highest case fatality of any infectious disease and a burden in excess of or comparative to other major zoonoses, rabies remains neglected. Once illness appears, no treatment is proven to prevent death. Paradoxically, vaccines were developed more than a century ago, but the clear majority of human cases are unvaccinated. Tens of millions of people are exposed to suspect rabid animals and tens of thousands succumb annually, primarily children in developing countries, where canine rabies is enzootic. Rather than culling animal populations, one of the most cost-effective strategies to curbing human fatalities is the mass vaccination of dogs. Building on considerable progress to date, several complementary actions are needed in the near future, including a more harmonized approach to viral taxonomy, enhanced de-centralized laboratory-based surveillance, focal pathogen discovery and characterization, applied pathobiological research for therapeutics, improved estimates of canine populations at risk, actual production of required vaccines and related biologics, strategies to maximize prevention but minimize unnecessary human prophylaxis,

version 1
23 Feb 2017
Faculty Reviews are review articles written by the
prestigious Members of Faculty Opinions. The
articles are commissioned and peer reviewed
before publication to ensure that the final,
published version is comprehensive and
accessible. The reviewers who approved the final
version are listed with their names and
affiliations.
.................................................................
1. Nicholas Johnson, Animal and Plant Health
Agency, Surrey, Surrey, UK
2. James Childs, Yale School of Public Health,
New Haven, USA

Any comments on the article can be found at the end of the article. 
and a long-term, realistic plan for sustained global program support to achieve success in disease control, prevention, and elimination.

\section{Keywords}

lyssaviruses, rabies, rabies vaccine, zoonoses

\section{Corresponding author: Charles Rupprecht (charleserupprechtii@gmail.com)}

Competing interests: The authors declare that they have no competing interests.

Grant information: The author(s) declared that no grants were involved in supporting this work.

Copyright: $\odot 2017$ Rupprecht C et al. This is an open access article distributed under the terms of the Creative Commons Attribution License, which permits unrestricted use, distribution, and reproduction in any medium, provided the original work is properly cited.

How to cite this article: Rupprecht C, Kuzmin I and Meslin F. Lyssaviruses and rabies: current conundrums, concerns, contradictions and controversies [version 1; peer review: 2 approved] F1000Research 2017, 6(F1000 Faculty Rev):184 https://doi.org/10.12688/f1000research.10416.1

First published: 23 Feb 2017, 6(F1000 Faculty Rev):184 https://doi.org/10.12688/f1000research.10416.1 


\section{Introduction}

Rabies is not a simple long-ago vestige, nightmarish myth, or literary allegory but rather a significant viral encephalitis with the highest case fatality of any conventional infectious disease. Who else, besides those afflicted and affected, should care about rabies today? Legions-including the true animal lover, anthropologist, administrator, caver, educator, environmentalist, farmer, medical professional, traveler, health economist, hiker, historian, humanist, industrialist, legislator, modeler, philanthropist, sociologist, student, conservation biologist, and life scientist, to name a few by vocation or avocation-curious for elevated self and situational awareness, caring for the common good, intrigued by this view of life from an applied microbiological and ecological perspective or challenged by the allure for professional intervention in nature, represented by the less-than-apparent "non-low-hanging fruit".

To simplify the infectious cycle of rabies, exposure is direct, not by environmental deposition, but rather individual-to-individual intra- and inter-specific transmission, usually occurring via bite. Millions of highly neurotropic virions are excreted intermittently in the saliva of a rabid host, days to weeks before overt morbidity and eventual demise, entering the peripheral nervous system of a bite recipient. In vivo, from local depots and centripetal transit in the axoplasm, primary replication occurs within neurons of the central nervous system (CNS). Thereafter, centrifugal passage occurs from the CNS to a number of highly innervated sites, including the salivary glands. Oral, mucosal, or transdermal delivery of virions occurs by normal daily mammalian interactions. Failing these routine modus operandi pathways, altered unusual behaviors offer a variety of options for secondary contacts. These may range from mania to paresis and paralysis, with deliberate transmission options of agonistic encounters and biting, increased movement outside of normal home range/territories, or acute death, with predation by others upon virion-laden tissues and organs of the affected host. If a productive infection ensues, the entry-reproduction-exit cycle is poised to begin anew after initiation, taking days, weeks, months, or (rarely) years of incubation before excretion or obvious clinical manifestation. Such obligate, parasitic virions ensure elegant self-transfer by exploitation of the normal through to the bizarre. Relatively distant viral familial relatives hail among invertebrates and plants, but warm-blooded vertebrates are the rabies-prone hosts. Although these agents predated Homo sapiens, their current distribution, abundance, and diversity likely exceed pre-historic comparisons, especially mediated during the Anthropocene period.

Among warm-blooded vertebrates, birds are susceptible to infection, but rabies predominates naturally among various mammalian populations. Within the Mammalia, a virtual alphabet soup of cases has been recorded, from the armadillo to the zebra. Rabies is a significant disease of domestic and wild mammals alike, yet its zoonotic aspect is the cause of major historical infamy. Few and privileged were the civilizations that did not describe the ravages of an entity akin to rabies, such that this infection has impacted art, literature, and cultural practices for millennia. By one small measure, during the time taken by a typical reader to peruse this article, more than 1,300 people will have been exposed to rabies virus (RABV). Annually, tens of thousands of persons will succumb, the majority children. Most are poor, have no access to modern medical care, and will die unreported, frequently at home in a rural village. If among other scales - on the basis of disability-adjusted life-year scores or health economic measures-rabies ranks within the topten list of neglected viral zoonoses, one would anticipate that the degree of philanthropic input would be roughly equivalent among such pathogens. Unfortunately, such is not the case. For example, several other neglected viral diseases may have a somewhat smaller presumed impact yet receive far greater attention for international support (Table 1). Not rooted entirely in science, a more holistic transdisciplinary philosophy assists in a better partial understanding of why such biomedical disparities persist between need and assistance, provoking a bootstraps approach in the field out of frustrated necessity in the face of apparent contradictions.

In light of meaningful global action for the public good, at what level should one come to terms with rabies in the 21st century? Management, control, prevention, elimination, eradication, and so on are often freely bandied about together in today's lexicon of disease deliberations but are not synonymous terms. Unlike smallpox or rinderpest, rabies is not a candidate for actual eradication today, given the extent of host breadth and diversity. However, rabies has at least three major attributes in common with those other two extinct viral pathogens: validated diagnostic protocols, safe and effective vaccines, and the epidemiological insight to apply those laboratory tools and licensed biologics for sound prevention and control practices. Somewhat paradoxically, based upon a century of experience, modern rabies management accomplishes, in a truly One Health capacity, what no other comparable zoonosis program can achieve in tandem: human cases prevented by avoiding defined exposure and seeking prophylaxis after exposure; primary canine and secondary species infections eliminated, by mass immunization; and significantly, wild carnivore viral perpetuation interrupted via oral vaccination efforts on a landscape scale. Building upon such apparent progress, this review aims to provoke renewed discussions on several of the current issues and challenges related to modern lyssavirus taxonomy, phylogeny, surveillance, prevention, treatment, control, and elimination, based in part upon the opinions of the authors, representing more than a century of collective person-years of introspective knowledge, skills, and abilities in the field-not as an historical aside alone, but rather within the context of evidence from the peer-reviewed literature, focusing upon relevant publications primarily within the past few years ${ }^{1-115}$. Our hope is, in some small manner, to educate, enlighten, engage, and enable others to participate meaningfully in these remaining endeavors, within the realm of a 'science of conviction'.

\section{An evolving viral taxonomy: what is in a name?}

Taxonomy, a formal attempt at objective, systematic classification and naming of entities in the complex milieu of life on earth, represented by plants, animals, and so on, also extends to the microbiological arena. Both RABV and a group of phylogenetically related viruses (all of which cause the acute progressive encephalomyelitis known as rabies) belong to the genus Lyssavirus, within the family Rhabdoviridae and the order Mononegavirales, the single-stranded, non-segmented, negative-sense RNA viruses. With active surveillance and technical advances offered by next-generation sequencing, the taxonomy of the Rhabdoviridae is developing with increased complexity and new rhabdoviruses are being characterized ${ }^{1}$. 
Table 1. Comparison of associated health parameters of two vector-borne diseases and human rabies transmitted by dogs ${ }^{a}$.

\begin{tabular}{|c|c|c|c|}
\hline & Yellow fever & Japanese encephalitis & Rabies \\
\hline Disease & $\begin{array}{l}\text { Mild to acute viral hemorrhagic } \\
\text { syndrome }\end{array}$ & Mild to severe viral encephalitis & Acute progressive viral encephalitis \\
\hline Etiology & Flavivirus & Flavivirus & Lyssavirus \\
\hline Distribution & $\begin{array}{l}\text { Endemic in tropics of about } \\
34 \text { African and about } 13 \text { Latin } \\
\text { American countries }\end{array}$ & $\begin{array}{l}\text { Endemic in about } 24 \text { Southeast } \\
\text { Asian and Western Pacific } \\
\text { countries }\end{array}$ & $\begin{array}{l}\text { Endemic within about } 150 \text { developing } \\
\text { countries in the Americas, Africa, and } \\
\text { Asia }\end{array}$ \\
\hline Transmission & Mosquito & Mosquito & Dog bite \\
\hline Case fatality & About $20-50 \%$ in severe cases & About $30 \%$ & $>99.9 \%$ \\
\hline Burden & $\begin{array}{l}\text { About } 84,000-170,000 \text { severe } \\
\text { cases }\end{array}$ & About 68,000 cases & >15 million exposures annually \\
\hline Annual fatalities & $\begin{array}{l}\text { About 29,000-60,000 estimated } \\
\text { deaths in Africa alone }\end{array}$ & $\begin{array}{l}\text { About 13,600-20,400 estimated } \\
\text { deaths }\end{array}$ & $\begin{array}{l}\text { About } 25,000-159,000 \text { estimated } \\
\text { deaths }\end{array}$ \\
\hline $\begin{array}{l}\text { Epidemiological } \\
\text { occurrence }\end{array}$ & $\begin{array}{l}\text { Sylvatic cycle and urban } \\
\text { outbreaks }\end{array}$ & $\begin{array}{l}\text { Major outbreaks about } 2-15 \text { years, } \\
\text { intensified during the rainy season }\end{array}$ & $\begin{array}{l}\text { Primarily individual human cases in } \\
\text { rural, underserved areas }\end{array}$ \\
\hline Vaccination & $\begin{array}{l}\text { One dose may be effective, with } \\
\text { long-term to lifelong immunity in } \\
\text { about } 99 \% \text { of people }\end{array}$ & $\begin{array}{l}\text { Primary and booster doses for } \\
\text { childhood Expanded Programme } \\
\text { on Immunization incorporation }\end{array}$ & $\begin{array}{l}\text { Currently, requires three or more doses } \\
\text { in pre- or post-exposure vaccination }\end{array}$ \\
\hline Treatment & Supportive care only & Supportive care only & $\begin{array}{l}\text { No specific treatment, comfort care } \\
\text { only before death }\end{array}$ \\
\hline Prospect for elimination & $\begin{array}{l}\text { Vaccination protects humans at } \\
\text { risk, but Yellow fever cannot be } \\
\text { eliminated in nature. }\end{array}$ & $\begin{array}{l}\text { Vaccination protects humans at } \\
\text { risk, but Japanese encephalitis is } \\
\text { not a candidate for elimination. }\end{array}$ & $\begin{array}{l}\text { Human rabies can be prevented by } \\
\text { vaccination and canine rabies can be } \\
\text { eliminated by mass dog vaccination. }\end{array}$ \\
\hline $\begin{array}{l}\text { Global Alliance } \\
\text { for Vaccines and } \\
\text { Immunization (GAVI) } \\
\text { support (by 2015) }\end{array}$ & >\$264 million USD & $\begin{array}{l}\text { About } \$ 105 \text { million USD forecast for } \\
2015-2020\end{array}$ & $\$ 0$ \\
\hline
\end{tabular}

aworld Health Organization (http://www.who.int/mediacentre/en/).

However, although new lyssaviruses are also being described, the genus forms a well-delineated cluster within the family and does not have any close relationships with other rhabdoviruses.

Recently, the International Committee on Taxonomy of Viruses (ICTV) moved toward a partial appropriation of binomial species nomenclature, which exists in other fields of taxonomy. However, the ICTV applied such naming inversely, so the genus name appears after the species name ${ }^{2}$. An objective rationale for this change is somewhat difficult to fathom unless the ICTV is trying to underline the fact that "real" virions and the concept of viruses and viral species are totally different entities. Although virions are observed by electron microscopy, no one has ever seen a "virus". Virions are particulate, whereas viruses are conceptual populations of microorganisms, and more so virus species are "polythetic classes" (or fabricated "containers") in which certain agents are placed artificially on the basis of their genetic, morphological, and physio-chemical properties $^{3}$. In other fields of biology, one would use the scientific name of an organism as the synonym for its species, but in virus taxonomy this is not the case. For example, now RABV belongs to the type species of the Lyssavirus genus, termed Rabies lyssavirus. So speaking in general of the virus as an organism, one still uses the former, whereas the latter is employed in a taxonomic context only. Inherited operational difficulties of use-for example, RABV (a virus) but Rabies lyssavirus (a species); Mokola virus (a virus) but Mokola lyssavirus (a species) and so on, also noting that virus names, but not species names, can be abbreviated-may lead to further changes of this binomial nomenclature in future years ${ }^{4}$.

Other species in the genus include Aravan lyssavirus, Australian bat lyssavirus, Bokeloh lyssavirus, Duvenhage lyssavirus, European bat lyssaviruses, type 1 and type 2, Ikoma lyssavirus, Irkut lyssavirus, Khujand lyssavirus, Lagos bat lyssavirus, Mokola lyssavirus, Shimoni bat lyssavirus, and West Caucasian bat lyssavirus ${ }^{2}$. Two other putative lyssaviruses do not yet have taxonomic status. One is Lleida bat lyssavirus (LLEBV), identified previously by only a partial genome sequence, while isolation attempts continue ${ }^{5}$. The other, soon to be submitted to the ICTV for review, is the most recently described Gannoruwa bat lyssavirus ${ }^{6}$. Lyssavirus phylogeny is depicted in Figure 1 (with colors of the branches applicable to Figure 2).

Globally, lyssaviruses have been subdivided into two phylogroups on the basis of genetic distances within their G-protein ectodomains and serologic cross-reactivity ${ }^{7}$. Phylogroup I includes Rabies lyssavirus, Aravan lyssavirus, Australian bat lyssavirus, Bokeloh lyssavirus, Duvenhage lyssavirus, European bat lyssaviruses, type 1 and type 2, Irkut lyssavirus, Khujand lyssavirus, and the new 


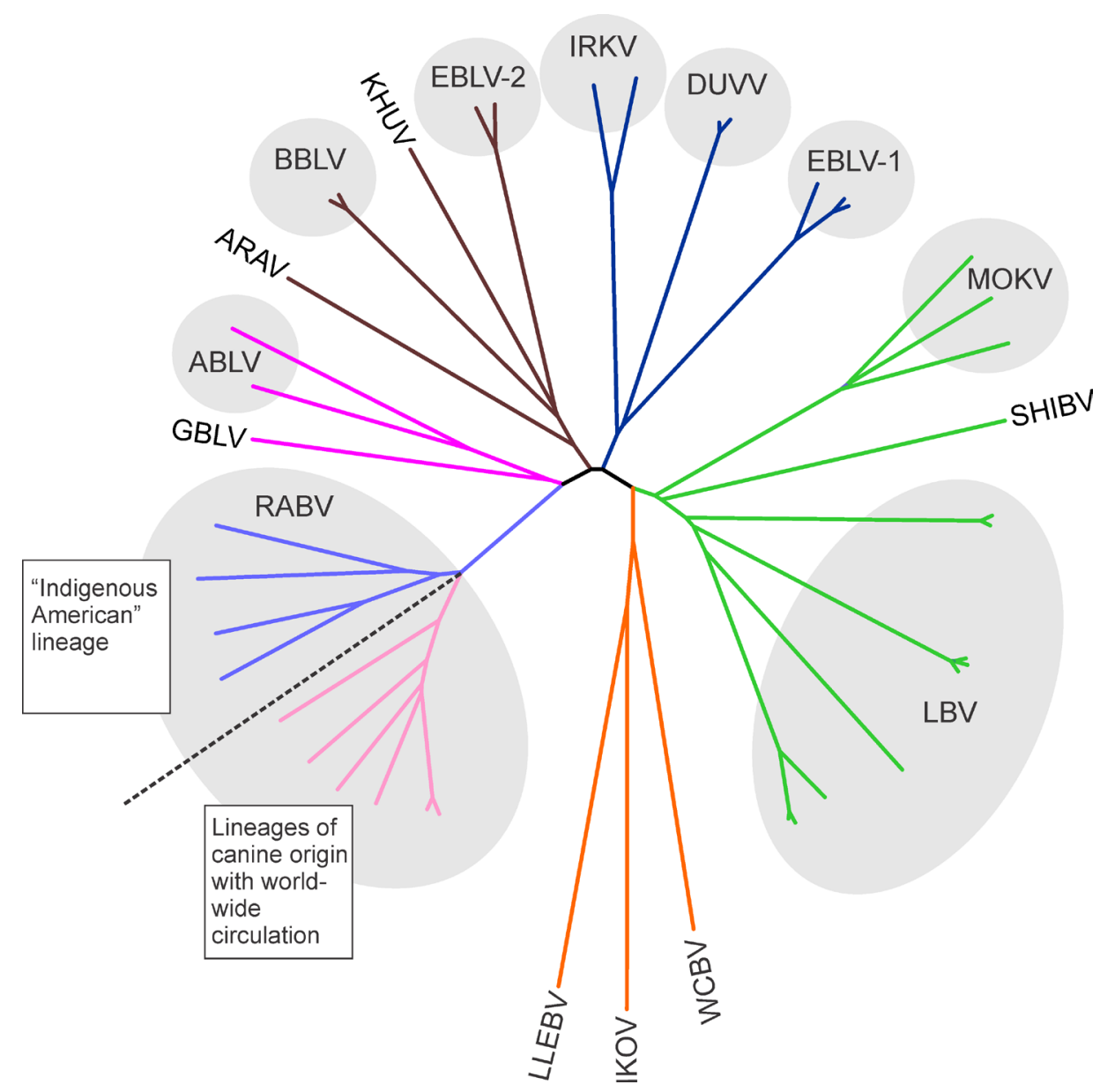

Figure 1. Extant lyssavirus phylogeny. Unrooted phylogenetic tree of currently recognized and putative lyssaviruses (neighbor-joining method, p-distances matrix). Lineage colors correspond to the same lyssaviruses depicted in Figure 2. ABLV, Australian bat lyssavirus; ARAV, Aravan virus; BBLV, Bokeloh bat lyssavirus; DUVV, Duvenhage virus; EBLV-1, EBLV-2, European bat lyssaviruses, type 1 and 2; GBLV, Gannoruwa bat lyssavirus; IKOV, Ikoma lyssavirus; IRKV, Irkut virus; KHUV, Khujand virus; LBV, Lagos bat virus; LLEBV, Lleida bat lyssavirus; MOKV, Mokola virus; RABV, Rabies virus; SHIBV, Shimoni bat virus; WCBV, West Caucasian bat virus.

Gannoruwa bat lyssavirus. Phylogroup II includes Lagos bat lyssavirus, Mokola lyssavirus, and Shimoni bat lyssavirus. The remaining West Caucasian bat lyssavirus, Ikoma lyssavirus, and Lleida bat lyssavirus are not included in either phylogroup. Although phylogenetically they do appear related, the amount of genetic divergence and absence of cross-neutralization do not allow placement in a single phylogroup on the basis of existing demarcation criteria ${ }^{8}$. Genetic distances between lyssaviruses from different species are significantly shorter than those in other rhabdovirus genera. Therefore, other characters, such as antigenic reactivity patterns with monoclonal antibodies and ecologic properties (including distribution and host range), are used imperfectly for demarcation between the viral species 9 . This demarcation is based on expert opinion of a well-qualified taxonomic study group. With increasing ICTV debate toward unification of virus taxonomy based on genetic distances, in the near future there may be a re-classification attempt, in which all phylogroup I viruses are segregated into one species (for example, Rabies lyssavirus?) and all phylogroup II viruses are segregated into another. Of course, such re-classification would miss important characteristics used for species demarcation at present and may have potential socio-economic or bio-political consequences for certain areas. For example, some places where RABV is not thought to circulate, such as in Australia or Western Europe (but where other lyssaviruses are present among bats), might lose their self-defined "rabies-free" status, on the basis of viral taxonomic re-organization, creating greater confusion, with potential public health, veterinary, or economic repercussions, if suddenly recast into the same disease status as Africa, Asia and the New World. Arguably, the term "rabies" appears to garner greater weight and seriousness than the less familiar designation "bat lyssavirus".

\section{A conundrum over lyssavirus origins, emergence, perpetuation-and extinctions?}

All phylogroup I lyssaviruses circulate in bats. Among these, only RABV is also adapted to perpetuation in carnivores. Within phylogroup II, both Lagos bat virus (LBV) and Shimoni bat virus are 


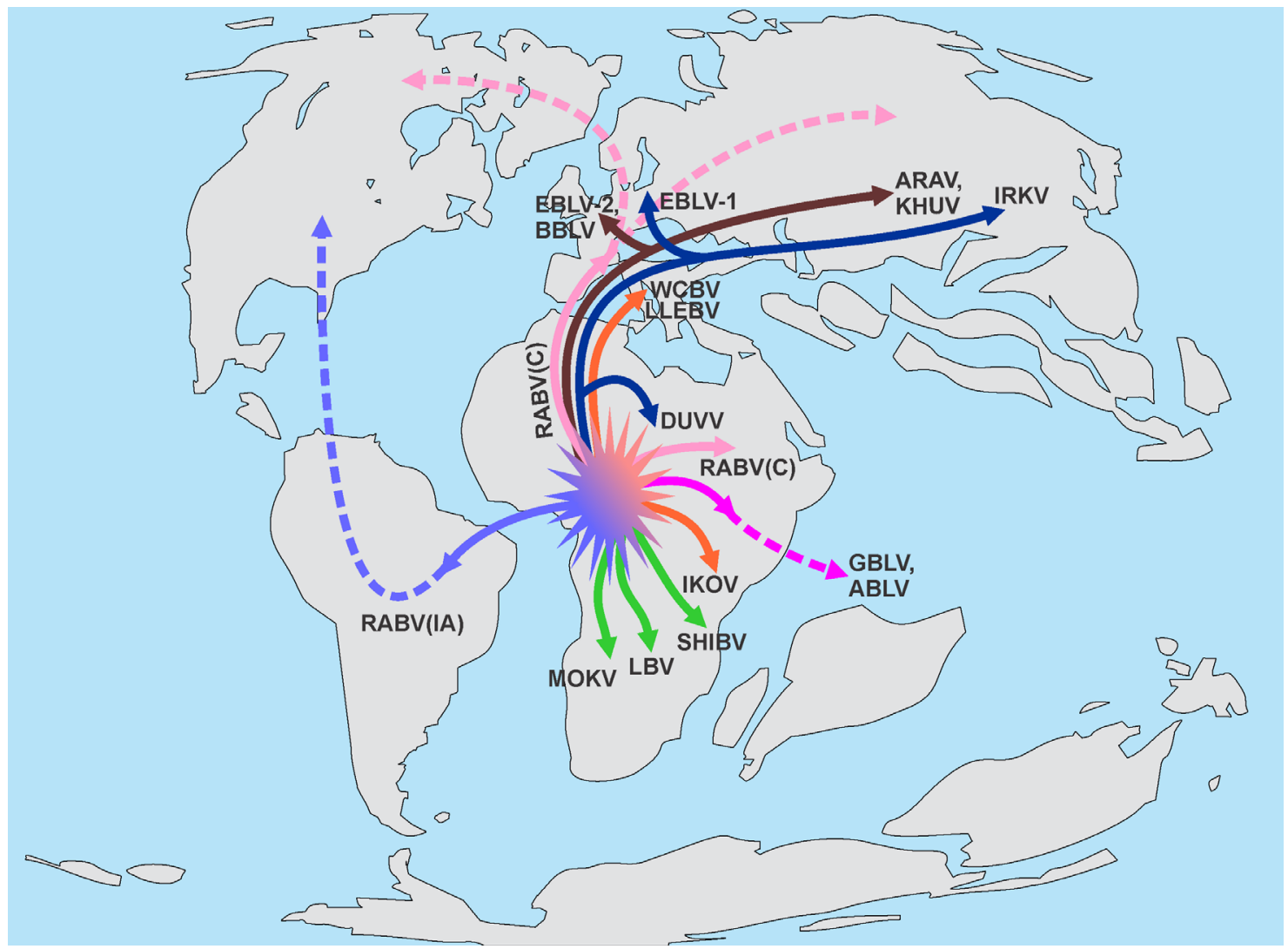

Figure 2. Proposed lyssavirus radiations. Highly speculative schematic depiction of the ancient spread of proto-lyssaviruses on a proposed map of the continents as they were present during the late Cretaceous period. Solid lines show hypothetical directions of lyssavirus ancestor distribution at that time, and dashed lines show further spread thereafter with additional continental drift. Although the "out of Africa" hypothesis dominates the scheme, this does not discount the potential role of Antarctica in biogeographic dispersal with bat-virus links to both Australia and South America as suggested for other pathogens ${ }^{93}$. ABLV, Australian bay lyssavirus; ARAV, Aravan virus; BBLV, Bokeloh bat lyssavirus; DUVV, Duvenhage virus; EBLV-1, EBLV-2, European bat lyssaviruses, type 1 and 2; GBLV, Gannoruwa bat lyssavirus; IKOV, Ikoma lyssavirus; IRKV, Irkut virus; KHUV, Khujand virus; LBV, Lagos bat virus; LLEBV, Lleida bat lyssavirus; MOKV, Mokola virus; RABV, rabies virus; RABV(IA), rabies virus, "indigenous American" lineage; RABV $(C)$, rabies virus, "carnivore" strain (further shifted to other host mammals); SHIBV, Shimoni bat virus; WCBV, West Caucasian bat virus.

bat-borne whereas the reservoir of Mokola virus (MOKV) remains unknown ${ }^{10}$. MOKV was isolated on a few occasions from shrews and from spill-over infections to cats and a $\operatorname{dog}^{11}$. The West Caucasian bat virus (WCBV) was isolated from a bat, and LLEBV genetic material was identified in a bat as well. Ikoma lyssavirus (IKOV) was isolated from an African civet, but phylogenetic relatedness of this virus to WCBV and LLEBV suggests that it might be a spillover infection, such that IKOV is actually a bat-borne virus as well ${ }^{8}$. Enhanced surveillance activities may help to resolve this point.

The evolutionary history of the lyssaviruses is very poorly understood. Common observations include strong purifying selection and neutral evolution of viral genomes ${ }^{12-14}$. The substitution rates along lyssavirus genomes are similar between viruses from different species and between different viral genes, approximating $3.8 \times$ $10^{-5}$ to $2.1 \times 10^{-3}$ substitutions per site per year ${ }^{13,15,16}$. An episodic diversifying selection was suggested in some studies, under a mixed effects model of episodic (MEME) selection. However, such endeavors failed to identify specific amino acid substitutions involved in host shifts with subsequent virus adaptation to a new host species (with increased fitness and fixation of favorable mutations) and as such should be interpreted cautiously ${ }^{15,16}$. This is not too surprising given that only the current sequences (sampled during the past 30 to 40 years from well-established reservoir species) were available for the analysis whereas the natural history of lyssavirus speciation is set in several orders of magnitude longer.

Extant lyssaviruses appear well adapted to their reservoir hosts. Comparison of LBV gene sequences sampled in South Africa over the past several decades revealed over $95 \%$ genome conservation ${ }^{17}$. In another study, the genome of LBV isolated in Kenya was $99 \%$ identical to the genome of another LBV isolate obtained in Senegal 22 years earlier ${ }^{18}$. Recent host shifts might help to elucidate the mechanisms of lyssavirus evolution but are not common. Spill-over infections usually result in dead-end events ${ }^{19}$. An empirical observation from several short-term host shifts of bat RABV to carnivores suggested that $S_{242}$ substitution in the viral $G$ protein might warrant fitness to bat hosts but that $\mathrm{A} / \mathrm{T}_{242}$ substitution is typical for 
carnivore-associated RABVs ${ }^{20}$. However, no further studies in the development of this hypothesis have been performed.

Early attempts to create a timescale for the natural history of lyssaviruses on the basis of substitution rates (molecular clocks) suggested that the most recent common ancestor (MRCA) of lyssaviruses existed 7,000 to 11,000 years ago but that the MRCA of the present RABV existed 900 to 1,500 years ago $^{12}$. In line with this, the MRCA age of North American bat RABVs was estimated to be 118 to 233 years $^{13}$ to 220 to 750 years $^{16,21}$.

Other studies that used essentially the same approaches and similar or slightly larger datasets extended the MRCA of bat RABVs to 436 to 1,107 years ${ }^{15}$ or to 500 years for one of the batassociated RABV lineages ${ }^{22}$. However, an increasing amount of evidence suggests that timescale estimation performed on a limited set of recently sampled sequences cannot provide realistic inferences for viruses evolving under constraints of purifying selection ${ }^{23}$. For example, an alternative approach with improved substitution saturation increased the MRCA of coronaviruses for several orders of magnitude compared with previous molecular clock estimates, and the resulting timescale was comparable to that of the coronavirus reservoir hosts ${ }^{24}$. In general, evolutionary rates observed in a set of sequences exhibit time dependency and are increased toward the present because of the transient mutations yet to be removed by purifying selection. Therefore, substitution rates estimated during long time frames will be lower systematically than those obtained during short time frames. This effect is as strong as, or stronger than, purifying selection, which shapes virus evolution ${ }^{25,26,27}$. In other words, timescale estimations based on substitution rates are useful only for the time frame encompassed by the sampling period but cannot be extrapolated easily for longer periods of time.

Present distributions, diversity and compartmentalization of lyssaviruses, and the empiric observation of viral genome conservation reveal great contrast to the suggested recent age of their MRCA. If one entertains that the published suggested timescale estimates of lyssaviruses are fallacious, restricted by analysis of limited sets of available isolates, one can use several other lines of evidence to hypothesize their origin and longer-term evolution. All the diversity of lyssaviruses is represented in bats (except for MOKV and IKOV, for which the reservoir hosts are yet to be established definitively), whereas carnivores maintain perpetuation of several lineages of RABV only. As such, it is commonly accepted that bats are the primary evolutionary hosts of lyssaviruses ${ }^{8,12,28}$. Lyssaviruses of multiple species (with the notable exception of RABV) circulate in Old World bats, but only RABV circulates in New World bats. Furthermore, RABV lineages present in New World bats, along with a few lineages circulating in skunks and raccoons (the so-called "indigenous American" RABV), are paraphyletic to the RABV lineages circulating in carnivores in the Old World and to the "cosmopolitan" canine lineage, which (as believed) was dispersed worldwide with human migrations across the globe ${ }^{29}$. Nevertheless, all RABV lineages are monophyletic when compared with lyssaviruses of other species and demonstrate a greater sequence identity between each other than to lyssaviruses of other species ${ }^{30}$. From this evidence, it is tempting to speculate that an ancient RABV ancestor (already distinct from lyssaviruses of other species) circulated in early bats in the territory of Gondwana, as bats presumably originated in the region of modern Africa ${ }^{31}$. A bat morphologically similar to extant bats, Onychonycteris, lived about 52.5 million years ago ${ }^{32}$. Other related species might have existed earlier. Molecular inferences suggested that the MRCA of present bats existed at least 80 million years ago, potentially pushing bat origins into the Cretaceous period ${ }^{31,33}$. Such an ancient chiropteran origin of RABV might explain the existence of the independently evolved "indigenous American" virus lineage and the absence of similar RABVs in related bat species between the Americas and the Old World (for example, in Myotis spp. and Eptesicus spp.). South America and Africa split from each other between 100 and 84 million years ago and were separated by the South Atlantic Ocean. Ancient bats are hypothesized to have spread from Africa to South America slightly later, via island hopping or direct intercontinental flight ${ }^{31}$. Perhaps, at that time, bats were already infected with a progenitor of the "indigenous American" RABV (Figure 2). This virus might be well adapted to bat hosts (for example, owing to substitutions such as $\mathrm{S}_{242}$ in the viral $\mathrm{G}$ protein) and compartmentalized in numerous bat species, such as the indigenous phyllostomatids, across the Americas, with a later host shift to other bat species, skunks, and raccoons. Phylogenetic analysis suggested rapid diversification of bats, with all families having evolved before the late Eocene epoch $^{31}$, and the same might be true for the viruses that co-evolved with their hosts, followed by millions of years characterized by stasis and slow genetic drift under constraints of purifying selection. Possibly, RABV lineages that continued to evolve in the Old World did not obtain such favorable substitutions and could not colonize multiple bat species as in the Americas but rather switched to carnivores as a comparatively recent event. Of course, this hypothesis does not explain the absence of RABV in Old World bats. However, given the less-than-ideal level of surveillance in the Old World tropics, it is possible that bat RABV does exist there but is undiscovered. Considering that four new lyssaviruses were described during the last decade (including Bokeloh bat lyssavirus in Western Europe, where surveillance is quite adequate) and that the most recent of these, Gannoruwa bat lyssavirus, was described in Sri Lanka in 2016 only $^{6}$, one should expect further discoveries of lyssaviruses in the Old World. The absence of non-RABV lyssaviruses in the Americas can be explained at least in part by the fact that even at present these viruses have a limited geographic distribution and host ranges compared with RABV. If these characteristics were similar in the past, such viruses might not spread to the territory of the present Americas once Africa and South America drifted further apart (Figure 2).

Alternatively, one can speculate that many viruses (including multiple bat RABVs in the Old World and non-RABV lyssaviruses in the New World) became extinct during the Cretaceous-Paleocene event 65 million years ago which, as estimated, wiped out $75 \%$ of all biologic species ${ }^{34}$. As major reservoirs went extinct, so too the viral species adapted to them. Though lacking to date for lyssaviruses, progress in the field of paleovirology and applications to other members of the Mononegavirales support the contention of time scales for some ancient viruses in excess of tens of millions of years in age, co-evolving with their hosts ${ }^{35}$.

\section{Neglect of laboratory-based surveillance systems}

In an applied One Health context, rabies diagnosis is the only routine procedure applied to a suspect animal that will directly 
determine the need for specific, life-saving medical intervention in a human at risk (http://www.cdc.gov/rabies/pdf/rabiesdfaspv2.pdf). Laboratory diagnosis is critical to confirm the status of a suspect case, in part, to justify prophylaxis in exposed persons or animals, to measure objectively the impact of disease prevention programs, and to support certification of a country as free of disease.

Sensitive, specific, economical, and timely diagnostic tests have been available for more than 50 years, and there has been increasing augmentation by molecular methods for routine rabies diagnosis ${ }^{10,36,37}$. Yet despite the innumerable rabies cases that occur in wildlife, domestic animals, and humans on a daily basis, only a very small fraction are diagnosed. Few resources are provided, because no cases are diagnosed, owing to a lack of support, producing a cycle of neglect that minimizes the true understanding of disease burden. Those at highest risk are often of lowest priority, such as the poor, the disenfranchised, and the non-agricultural commodities represented by free-ranging wildlife or community dogs.

Misdiagnosis may result with the presentation of fever and coma in children because of confusion with other diseases, such as cerebral malaria $^{38}$. Conversely, in some situations, a history of animal bite may be missing because the patient does not realize that exposure has occurred, such that rabies does not enter the original differential diagnosis of encephalitis ${ }^{39}$. The relationship between exposure and illness may be forgotten, and patient recall may be disconnected because of the lag from the incubation period, which can extend beyond weeks to months or even years ${ }^{40}$. Moreover, the national laboratory may be located centrally in an urban capital, far from case occurrence in rural areas.

The consequences of neglect are obvious. For example, when juveniles contact rabid puppies, the diagnostic event is missed, the prophylaxis opportunity is gone, and the child dies ${ }^{41}$. If rabies is not suspected in an infected donor, organs may be transplanted from a patient that dies acutely, producing additional fatal cases in the recipients ${ }^{42}$. Beyond the individual, at a global level, the frequent lack of inclusion of wildlife in surveillance efforts may mean the difference between a misjudged, rabies-free locality and a newly appreciated enzootic area ${ }^{43}$. Similarly, translocation of a rabid dog from a canine-enzootic area can threaten the status of another area that has eliminated canine RABV circulation, after great cost and years of effort ${ }^{44}$. Such reports of importation are not uncommon in the literature, online sources such as ProMED, or communication in the daily news (http://www.animals24-7.org/2014/06/08/dog-meattraffic-still-spreads-rabies-in-vietnam/).

Although it is highly desirable to document the presence of new lyssaviruses during pathogen discovery, the basic surveillance information needed to prevent and control what is already known about RABV and its impact upon public health, agriculture, and conservation biology, using available, practical diagnostic tools, is more important (Table 2).

\section{Prophylaxis concerns}

Often forgotten, rabies qualifies as a vaccine-preventable disease. Effective rabies biologics have been available for over a century ${ }^{45}$. Pre-exposure vaccination is highly efficacious for those at risk of exposure, such as veterinarians, laboratory workers, and certain travelers ${ }^{46,47}$. After exposure, the prompt and proper application of post-exposure prophylaxis (PEP)—consisting of wound care, infiltration of rabies immune globulin (RIG), and administration of modern rabies vaccines-virtually ensures survival ${ }^{48}$. Nevertheless, the majority of persons at risk do not receive preexposure vaccination and most RABV-exposed patients are never provided adequate PEP. This discrepancy between Advisory Committee on Immunization Practices/World Health Organization (ACIP/WHO) recommendations and reality has sparked strong debate and translational research for more novel, less expensive products; simplified schedules; and improved ease of use $\mathrm{s}^{49-58}$. Outstanding questions for resolution include the following: Can PEP be performed safely without RIG (given that limited availability means more than $90 \%$ of persons do not receive it)? Are heterologous (for example, equine) RIG products equivalent to human RIG in regard to safety and effectiveness? If so, how should their production be increased? Is the dose of RIG critical in terms of international units per kilograms or is local infiltration more important, regardless of absolute dose? Does administration of vaccine directly into exposure sites improve survivorship if RIG is not available? Could PEP completion be reduced to one week or less? What is the role for rabies pre-exposure vaccine inclusion into childhood schedules? When will GAVI add human rabies vaccine to its portfolio? Will monoclonal antibodies help to resolve the issues with RIG availability and distribution? Should new biologics be developed to increase the breadth of reactivity against non-phylogroup I lyssaviruses? Is there a role for new adjuvants or attenuated RABV vaccines to obviate the need for RIG? Should genes involved in the innate immune response (for example, interferons) be incorporated into genomes of recombinant RABV vaccine strains? Although the field will always profit from relevant advances, much attention is often spent on academic research on new biologics and less on translational research for the appropriate use of existing products and protocols to prevent rabies now (Table 3).

\section{Controversy on the horizon: a paradigm shift to treating the "incurable wound"?}

Today, as in the past, a diagnosis of a rabies case is, in a statistical sense ( $>99.9 \%$ ), synonymous with fatality. There is no proven treatment once clinical signs appear. This presents a huge dilemma to the clinician faced with a rabies patient, with few options ${ }^{59}$. For a veterinarian, the animal is euthanized. For a physician, the patient may be placed in isolation, and at a minimum palliative care needs to be provided.

Alternatively, the person may be sent home to die. Cumulatively, since the 1970s, reports of very rare, non-fatal human cases (most with a history of vaccination) and the occasional spontaneous "survivor" during animal rabies studies suggested that clinical rabies may not always end in death, prompting the administration of aggressive anti-viral therapy ${ }^{60}$. As a case in point, in 2004, a Wisconsin teenager bitten by a bat became the first unvaccinated survivor after intensive medical care, coma induction, and administration of anti-viral drugs ${ }^{61}$. Over the next decade, few additional survivors who received the "Milwaukee protocol" were added to the registry (http://www.mcw.edu/Pediatrics/InfectiousDiseases/PatientCare/Rabies.htm). Nevertheless, the drive to act is understandable; such undertakings are compassionate and heroic attempts at treating the incurable. Who can witness the face of 
Table 2. Problems and options for improved lyssavirus laboratory-based surveillance.

\begin{tabular}{|c|c|c|}
\hline Apparent issues & Proposed resolution & References \\
\hline Few reported suspect cases & $\begin{array}{l}\text { Improved enhanced or active } \\
\text { surveillance }\end{array}$ & 94 \\
\hline $\begin{array}{l}\text { Confusion over which test to use } \\
\text { for primary case confirmation }\end{array}$ & $\begin{array}{l}\text { Direct fluorescent antibody test } \\
\text { implementation on central nervous } \\
\text { system (CNS) tissue (gold standard) }\end{array}$ & 10 \\
\hline $\begin{array}{l}\text { Limited budget for fluorescent } \\
\text { microscopic equipment }\end{array}$ & $\begin{array}{l}\text { Direct rapid immunohistochemistry } \\
\text { test }\end{array}$ & 95 \\
\hline $\begin{array}{l}\text { Biosafety concerns of animal } \\
\text { CNS removal }\end{array}$ & Focus upon brainstem collection & 96 \\
\hline $\begin{array}{l}\text { Few trained field staff for } \\
\text { de-centralized surveys }\end{array}$ & $\begin{array}{l}\text { Linear flow assay (LFA) screening } \\
\text { with confirmatory testing }\end{array}$ & 97 \\
\hline Insensitivity of existing LFA tests & $\begin{array}{l}\text { Improved commercial lot release } \\
\text { and licensing }\end{array}$ & 98 \\
\hline $\begin{array}{l}\text { Need for basic virus variant } \\
\text { identification }\end{array}$ & Monoclonal antibody typing & 99 \\
\hline $\begin{array}{l}\text { Cultural sensitivity over human } \\
\text { autopsy performance }\end{array}$ & $\begin{array}{l}\text { Antemortem collection of skin } \\
\text { biopsy, serum, cerebrospinal fluid } \\
\text { (CSF), and saliva swabs }\end{array}$ & 100 \\
\hline $\begin{array}{l}\text { Requirement for rapid, sensitive, } \\
\text { and specific identification of } \\
\text { suspect human cases }\end{array}$ & $\begin{array}{l}\text { Real-time polymerase chain reaction } \\
\text { of human saliva and biopsy samples }\end{array}$ & 101 \\
\hline $\begin{array}{l}\text { Inability for virus neutralization } \\
\text { tests of clinical samples }\end{array}$ & $\begin{array}{l}\text { Enzyme-linked immunosorbent } \\
\text { assay-based tests of serum and } \\
\text { CSF }\end{array}$ & 102 \\
\hline $\begin{array}{l}\text { Desire for greater epidemiological } \\
\text { investigation of confirmed cases }\end{array}$ & Whole genome sequencing & 103 \\
\hline $\begin{array}{l}\text { Need for deep identification of } \\
\text { viral quasispecies }\end{array}$ & Next-generation sequencing & 104 \\
\hline
\end{tabular}

pathos in a Manila rabies ward and not be sensitized (http://www. aljazeera.com/programmes/lifelines/2013/09/rabies-lifelines-isolation-patient-2013923164345829402.html)? Who can listen to the heart-breaking personal impact of rabies on a family and not feel moved (https://www.youtube.com/watch?v=u8o1tOuyghk)? Who can watch "The Girl Who Survived Rabies" and not feel compelled (https://www.youtube.com/watch?v=qdPuXHhEwDk)? Although there has been sharp debate over the dangers of therapeutic coma and the merits of the Milwaukee protocol, the often-heated discussion has reinvigorated the field in a direction toward consideration of potential treatment administered to the patient with rabies ${ }^{62}$. Asklepios is but one example of such a renaissance by a consortium of scientists whose focal research aims include the following: the identification of drugs that would inhibit RABV replication, the testing of molecules that may minimize detrimental host responses during RABV infection, the determination of whether alteration of the blood-brain barrier (BBB) permeability could improve treatment effectiveness, and validation of the potential success for such an approach in vivo (http://asklepiosfp7.eu/). Regardless of technical insights, required expertise, the associated expense and related ethics of effort issues, there is also the prospect of survivorship with sequelae and the need for lengthy, potentially lifelong, rehabilitation and quality-of-life considerations ${ }^{63}$.
To make progress, whether in veterinary or human medicine, a more complete approach to rabies treatment should be taken, combining insights on rabies pathobiology gleaned from both experimental animal research and individual human case studies $^{64}$. Excellent clinical care by a dream team of specialists, anti-viral drugs incorporated from other RNA virus research, targeted immune modulation, the tincture of time, and a healthy dose of luck for appreciable self-cure in a patient with the ideal age, genetic pre-disposition, and clinical staging parameters may offer future hope to a more prescriptive treatment of rabies (Table 4).

\section{Concerns over vaccine needs to achieve global human and dog rabies elimination-by 2030}

Throughout the late-20th and early-21st centuries, target dates for the elimination of human-dog-mediated rabies were set by the WHO, the Pan American Health Organization, and other international governmental and non-governmental organizations for Africa, Asia, and Latin America (65-68 http://www.paho. org/hq/index.php?option=com_content $\&$ view=article $\&$ id $=1124$ 3:step-up-action-toward-rabieselimination \&Itemid=1926\&lang $=e n)$. These recent end dates were endorsed by the World Health Assembly in May $2013^{69}$. 
Table 3. Risk assessment to maximize the utility of rabies prophylaxis after human exposure ${ }^{10,48,75}$.

\begin{tabular}{|c|c|c|}
\hline Category & Issue & Outcome \\
\hline Species & Is the mammal a reservoir? & Non-reservoirs or non-vectors are less likely to be rabid. \\
\hline Exposure & Was the exposure due to a bite? & Non-bite exposures are less likely to cause rabies. \\
\hline Health & $\begin{array}{l}\text { Does the animal show compatible clinical } \\
\text { signs with an encephalitis or other behavioral } \\
\text { abnormalities suggestive of rabies? }\end{array}$ & $\begin{array}{l}\text { In general, apparently healthy animals (even near the end } \\
\text { of the incubation period) are less likely than ill animals to } \\
\text { excrete virus. }\end{array}$ \\
\hline $\begin{array}{l}\text { Epidemiological } \\
\text { status }\end{array}$ & What is the occurrence of rabies in the area? & $\begin{array}{l}\text { Unless an epizootic or enzootic status is apparent, rabies } \\
\text { is less frequent in areas without cases for several years, } \\
\text { assuming adequate laboratory-based surveillance. }\end{array}$ \\
\hline $\begin{array}{l}\text { Event } \\
\text { circumstances }\end{array}$ & Was the exposure provoked? & $\begin{array}{l}\text { Often animals may bite if provoked (for example, protecting } \\
\text { young, sleeping, or eating). }\end{array}$ \\
\hline Observation & Can the dog, cat, or ferret be observed? & $\begin{array}{l}\text { If the animal stays apparently healthy during at least } 10 \\
\text { days after the bite, no post-exposure prophylaxis (PEP) is } \\
\text { needed (or initiated PEP can be discontinued). }\end{array}$ \\
\hline $\begin{array}{l}\text { Vaccination } \\
\text { status }\end{array}$ & Is the animal up to date on rabies vaccination? & $\begin{array}{l}\text { Vaccine failures are possible, but rare, with modern } \\
\text { veterinary biologics. }\end{array}$ \\
\hline Diagnosis & Is the brain available for a timely examination? & $\begin{array}{l}\text { If no rabies virus antigens are detected by a qualified } \\
\text { laboratory using an approved test, no PEP is needed. }\end{array}$ \\
\hline First aid & Were all wounds washed well? & $\begin{array}{l}\text { Proper cleansing with soap and water reduces the viral } \\
\text { load in local wounds. }\end{array}$ \\
\hline Injury & Does the injury require sutures? & $\begin{array}{l}\text { If at all practical, suturing should be postponed, to avoid } \\
\text { the opportunity to further contaminate the locality and drive } \\
\text { virus deeper in tissues. }\end{array}$ \\
\hline Biologics & $\begin{array}{l}\text { Are modern vaccines and rabies immune globulin } \\
\text { (RIG) available? }\end{array}$ & $\begin{array}{l}\text { If the diagnosis is positive or (under the worst conditions } \\
\text { when rabies is strongly suspected) if an unprovoked bite is } \\
\text { from an ill, unavailable dog or other reservoir in an enzootic } \\
\text { area, begin PEP per current World Health Organization } \\
\text { recommendations to the extent possible or support } \\
\text { transport to the nearest suitable facility immediately. }\end{array}$ \\
\hline Patient health & Is the person immune-competent? & $\begin{array}{l}\text { In the severely immune-suppressed patient, such as } \\
\text { someone with AIDS, passive immunization with rabies } \\
\text { immune globulin (RIG) becomes an even more critical part } \\
\text { of PEP. }\end{array}$ \\
\hline
\end{tabular}

The main components of this human rabies elimination program are control, prevention, and eventual elimination of rabies in dogs by mass immunization. Successive annual vaccination campaigns, reaching at least $70 \%$ of the dog population, led to progressive disease control and ultimately elimination in both dogs and humans ${ }^{10,68}$. Estimating the number of canine vaccine doses needed by country, WHO region, and finally globally over time to achieve these goals is of upmost importance. Understandably, dog rabies vaccine production and access have not received the same attention as human rabies biologics, even though the latter are still in somewhat limited availability, particularly in rural areas. Today, overall dog vaccination coverage is estimated to be less than $20 \%$ in canine rabiesendemic countries outside of the Americas (Table 5).

There is relatively little production, technology development or transfer, import, and subsequent use of canine vaccines in dog rabies-enzootic countries. To prevent rabies in humans, manufacturers from the Northern Hemisphere and an increasing number of producers from emerging markets (for example, China and India) produce enough vaccine annually to deliver approximately 28 million rabies PEP courses in dog rabies-enzootic countries of Africa, Asia, and the Eastern Mediterranean region, preventing nearly $98 \%$ of human rabies deaths. Unfortunately, easier access to rabies vaccine, particularly in urban centers of Africa and Asia, has been accompanied by an increasing proportion of PEP (sometimes up to 70\%) administered to people who are not at high risk of developing rabies, necessitating greater education and outreach to the public and professionals alike ${ }^{70}$. Such issues are not uncommon in Europe and North America, where human rabies caused by dogs has been eliminated.

A canine rabies vaccine bank was established in 2012 by the World Animal Health Organization (OIE), with multi-donor support to assist Asian countries initiating (for example, Afghanistan, Laos, and Myanmar) or strengthening (for example, the Philippines, Sri Lanka, and Vietnam) their immunization campaigns ${ }^{71,72}$. Though certainly useful, the quantities provided (about 3.7 million doses from 2012 to April 2015) have remained limited in comparison with annual requirements of full-fledged national programs in 10 Asian beneficiary countries. For example, over 3 years, Vietnam received a total of about 1 million doses, but nearly 10 million local dogs need to be vaccinated annually. Similarly, the WHO has expressed 


\begin{tabular}{|c|c|c|}
\hline Proposed need & Suggested consideration & References \\
\hline $\begin{array}{l}\text { Management of the dying rabies } \\
\text { patient? }\end{array}$ & Responsible palliative care, toward death with dignity & 105 \\
\hline $\begin{array}{l}\text { Intensive care of acute progressive } \\
\text { rabies encephalitis? }\end{array}$ & $\begin{array}{l}\text { Ventilation, sedation, cardiac monitoring, body } \\
\text { temperature regulation, parenteral nutrition, } \\
\text { management of vasospasm, and so on }\end{array}$ & 106 \\
\hline Real-time diagnostic support? & $\begin{array}{l}\text { Rapid antemortem confirmation, viral characterization, } \\
\text { and continued patient monitoring, including serology, } \\
\text { amplicons, antigens, and so on }\end{array}$ & 107 \\
\hline Active immunization? & Recombinant vaccines & 108 \\
\hline Passive immunization? & Rabies immune globulin or monoclonal antibodies & 109 \\
\hline $\begin{array}{l}\text { Administration of immunostimulatory } \\
\text { oligonucleotides? }\end{array}$ & Use of PyNTTTTGT compounds, such as IMT504 & 110 \\
\hline Anti-viral drugs? & $\begin{array}{l}\text { Use of known ssRNA virus inhibitors, such as } \\
\text { favipiravir (T-705) }\end{array}$ & 111 \\
\hline $\begin{array}{l}\text { Targeted host-catalyzed biochemical } \\
\text { pathways? }\end{array}$ & $\begin{array}{l}\text { Selection of specific small-molecular-weight } \\
\text { compounds }\end{array}$ & 112 \\
\hline $\begin{array}{l}\text { Blood-brain barrier permeability } \\
\text { enhancement? }\end{array}$ & $\begin{array}{l}\text { Induction of pro-inflammatory chemokines and } \\
\text { cytokines }\end{array}$ & 113 \\
\hline $\begin{array}{l}\text { Associated pathological decrease } \\
\text { of dopaminergic and serotoninergic } \\
\text { neurotransmission? }\end{array}$ & Supplementation with biotin & 114 \\
\hline $\begin{array}{l}\text { Mitochondrial dysfunction and } \\
\text { degenerative changes in neuronal } \\
\text { processes? }\end{array}$ & Relief of potential oxidative stress & 115 \\
\hline
\end{tabular}

an intention of constructing a human rabies vaccine stockpile to rapidly provide quality-ensured vaccines upon request ${ }^{73}$. Globally, human rabies vaccine quantities produced seem close to adequate, but at a country level, major challenges include the following: assessing unnecessary or inappropriately applied PEP, particularly in urban centers; bringing appropriately staffed "bite treatment centers" to needed communities; providing free or low-cost rabies biologics; and applying economical and easier-to-use PEP regimens to exposed patients $^{56}$.

A meeting was held at the WHO in 2015 on human and dog rabies vaccines and RIG. Objectives were to discuss forecasting needs, vaccine and RIG quality, and funding and procurement issues, and to estimate quantities of human and dog vaccines needed in the medium and long term at both the country and regional level ${ }^{74}$. During this meeting, manufacturers of canine rabies vaccines stated that production capacity shortages were not an issue and that output could be increased easily should accurate, financially supported, medium-term vaccine forecasts become available. However, current annual production capacities of major manufacturers are estimated to be near 100 million doses, and maximum capacity is about 150 million doses ${ }^{75}$. This rabies vaccine production is meant to satisfy the most profitable Northern Hemisphere (for example, USA, Canada, and Western and Eastern Europe) markets, where there are about 170 million owned dogs, whereas only a small share of the 411 million owned and community dogs are vaccinated each year in the defined WHO African, Asian, Eurasian, and
Middle Eastern regions (Table 5). The vaccine requirements of Latin American countries, where dog-mediated human rabies has almost been eliminated (mostly through dog rabies immunization), are estimated at about 42 million doses annually and often are covered largely by local manufacturers based in Mexico and Brazil ${ }^{76,77}$. Together, dog rabies-enzootic countries of Central Asia belonging to the European (EU), South-East-Asian (SEA), and Western Pacific (WP) WHO regions account in nearly equal proportions for almost $74 \%$ of the total number of canine vaccine doses used. Africa and Eastern Mediterranean regions account for the remaining $15 \%$ and $11 \%$, respectively.

The number of vaccine doses needed in canine rabies-enzootic countries of the defined WHO Africa, Asia, Eurasia, and East Mediterranean regions were estimated in the medium (2015-2020) and longer (2020-2029) terms to achieve the goal of human and dog rabies elimination. As a given, these vaccines should comply with all international norms and standards $s^{10,37,78}$. In the computing of estimates, one of the most sensitive figures is the human/dog ratio by geographical areas/WHO regions and large countries (China and India). Numbers of dogs per human and country clustering have been used from earlier publications ${ }^{70,79}$. Some dog rabies-enzootic countries were added to existing lists. When country-specific data were unavailable, the average estimate from countries within the cluster was applied. Table 6 provides a list of more than $85 \mathrm{dog}$ rabies-enzootic countries with their human and dog populations and dogs-per-human ratio in Africa, Asia, and East Mediterranean regions on the basis of prior work ${ }^{70,80,81}$. 
Table 5. Estimated dog populations, annual dog vaccine coverage and number of dog vaccine doses used per WHO region, including China (WPR) and India (SEAR).

\begin{tabular}{|c|c|c|c|c|c|}
\hline $\begin{array}{l}\text { Elimination } \\
\text { target date }\end{array}$ & WHO region & $\begin{array}{l}\text { Estimated dog } \\
\text { population (Table 6) }\end{array}$ & $\begin{array}{l}\text { Estimated } \\
\text { vaccination coverage } \\
\text { (see source below) }\end{array}$ & $\begin{array}{l}\text { Dog vaccine doses } \\
\text { used annually (in } \\
\text { millions of doses) }\end{array}$ & $\begin{array}{l}\text { Percentage of total } \\
\text { vaccine doses } \\
\text { applied }\end{array}$ \\
\hline \multirow[t]{7}{*}{2020} & EUR (Eurasia) & $85,612,000$ & $22 \%$ & 19 & 24.5 \\
\hline & EMR & $26,547,000$ & $32 \%$ & 8.5 & 11 \\
\hline & $\begin{array}{l}\text { SEAR, without } \\
\text { India }\end{array}$ & $72,631,000$ & $20 \%$ & 14.8 & 19.1 \\
\hline & India (72\% rural) & $38,109,000$ & $15 \%$ & 5.8 & 7.5 \\
\hline & $\begin{array}{l}\text { WPR, without } \\
\text { China }\end{array}$ & $38,847,000$ & $19 \%$ & 7.3 & 9.4 \\
\hline & $\begin{array}{l}\text { China (55\% } \\
\text { rural) }\end{array}$ & $71,785,000$ & $14 \%$ & 10 & 13 \\
\hline & $\begin{array}{l}\text { Totals for EMR, } \\
\text { EUR, SEAR, and } \\
\text { WPR }\end{array}$ & $333,531,000$ & $20 \%$ & 65.4 & 84.5 \\
\hline \multirow[t]{2}{*}{2030} & AFR total & $77,417,000$ & $16 \%$ & 12 & 15.5 \\
\hline & $\begin{array}{l}\text { Grand total } \\
\text { WHO regions } \\
\text { (but AMR) }\end{array}$ & $411,000,000$ & $20 \%$ & 77.4 & 100 \\
\hline
\end{tabular}

AFR, African Region; AMR, Region of the Americas; EMR, East Mediterranean Region; EUR, European Region; SEAR, South East Asia Region; WHO, World Health Organization; WPR, West Pacific Region.

\begin{tabular}{|c|c|}
\hline Region & Supportive notes and references \\
\hline Eurasia (EUR) & $22 \%{ }^{70}$ \\
\hline $\begin{array}{l}\text { Eastern Mediterranean Region } \\
\text { (EMR) }\end{array}$ & $32 \%$ \\
\hline $\begin{array}{l}\text { South East Asia Region (SEAR), } \\
\text { without India }\end{array}$ & $\begin{array}{l}\text { Sum of number of dogs vaccinated in SEAR countries belonging to clusters Asia } 2,3 \text {, and } 4 \\
\text { plus Indonesia according to estimated vaccination coverages (respectively } 9,5,36 \text {, and } 24 \% \\
\text { in } 70 \text { ) divided by an estimated total dog population of about } 72.6 \text { million }\end{array}$ \\
\hline India & 15\% (from 70) applied to estimated rural dog population of India (Table 6) \\
\hline $\begin{array}{l}\text { West Pacific Region (WPR), without } \\
\text { China }\end{array}$ & $\begin{array}{l}\text { Sum of number of dogs vaccinated in WPR countries belonging to clusters Asia } 2,3 \text {, and } 4 \\
\text { plus Mongolia according to vaccination coverage }(5.9 \% \text { from } 70 \text { ) divided by estimated total } \\
\text { dog population of } 38.8 \text { million (Table } 6)\end{array}$ \\
\hline China & Coverage $14 \%{ }^{70}$ applied to estimated rural dog population of China (Table 6) \\
\hline African region & $\begin{array}{l}\text { North Africa dog immunization coverage } 10 \% \text {, Southern Africa Development Community } \\
\text { (SADC) coverage } 23 \% \text {, West Africa coverage } 10 \% \text {, and rest of Africa } 9 \% \text { applied to } \\
\text { estimated dog population of relevant geographical clusters (Table } 6 \text { ), giving for North Africa: } \\
0.7 \text { million dogs vaccinated, for SADC: } 7 \text { million, West Africa: } 2 \text { million and rest of Africa: } \\
2.5 \text { million. Total Africa: } 12.2 \text { million. Dog vaccination coverage Africa: } 16 \%\end{array}$ \\
\hline
\end{tabular}

Using the above population estimates to compute canine vaccine needs over time, we used a conservative 10-year country-based dog rabies elimination model divided into a 5-year attack phase, a 3-year consolidation phase, and a 2-year maintenance phase (with vaccination coverages decreasing from $70 \%$ to $20 \%$ and finally to $5 \%$ as the program moved from one phase to another). This model is based on both theoretical and field experiences ${ }^{82-86}$. Understandably, national programs will progress at various paces. Some may need shorter or longer attack, consolidation, or maintenance phases than others. Ten years of sustained dog rabies immunization activities were considered long enough to bring human rabies cases down toward zero in most places, if carried out with the joint leadership of the countries and major international organizations ${ }^{87}$.

Dog vaccine requirements per country were aggregated by WHO regions and time periods. The results of estimated dog vaccine requirements by WHO regions and large countries (for example, China and India) are presented in Table 7. For the European (Eurasia cluster), East Mediterranean, Asian, and Western Pacific 
Table 6. Numbers of dogs per human and estimated dog populations per geographical areas, countries and World Health Organization regions.

\begin{tabular}{|c|c|c|c|c|c|c|}
\hline $\begin{array}{l}\text { Geographic } \\
\text { area }\end{array}$ & WHO region & Country & $\begin{array}{l}\text { Human } \\
\text { population } \\
\text { (estimated) }\end{array}$ & $\begin{array}{l}\text { Percentage } \\
\text { rural }\end{array}$ & $\begin{array}{l}\text { Human/ } \\
\text { dog ratio }\end{array}$ & $\begin{array}{l}\text { Dog population } \\
\text { (estimated) }\end{array}$ \\
\hline \multicolumn{7}{|l|}{$\begin{array}{l}\text { Asia and } \\
\text { Eurasian }\end{array}$} \\
\hline \multirow[t]{6}{*}{ Asia 2} & WPR & Cambodia & $15,135,169$ & $80 \%$ & 6.60 & $2,293,207$ \\
\hline & WPR & Laos & $6,769,727$ & $66 \%$ & 6.60 & $1,025,716$ \\
\hline & SEAR & North Korea & $24,895,480$ & $40 \%$ & 6.60 & $3,772,042$ \\
\hline & WPR & South Korea & $50,219,669$ & $17 \%$ & 6.60 & $7,609,041$ \\
\hline & SEAR & Myanmar & $53,259,018$ & $63 \%$ & 6.60 & $8,069,548$ \\
\hline & WPR & Vietnam & $89,708,900$ & $69 \%$ & 6.60 & $13,592,258$ \\
\hline \multirow[t]{4}{*}{ Asia 3} & SEAR & Bangladesh & $156,594,962$ & $72 \%$ & 14.70 & $10,652,719$ \\
\hline & SEAR & Bhutan & 753,947 & $64 \%$ & 14.70 & 51,289 \\
\hline & EMR & Pakistan & $182,142,594$ & $64 \%$ & 14.70 & $12,390,653$ \\
\hline & SEAR & Nepal & $27,797,457$ & $83 \%$ & 14.70 & $1,890,983$ \\
\hline \multirow[t]{4}{*}{ Asia 4} & WPR & Philippines & $98,393,574$ & $51 \%$ & 7.00 & $14,056,225$ \\
\hline & SEAR & Sri Lanka & $20,483,000$ & $85 \%$ & 7.00 & $2,926,143$ \\
\hline & SEAR & Thailand & $67,010,502$ & $66 \%$ & 7.00 & $9,572,929$ \\
\hline & $\begin{array}{l}\text { Total Asia } \\
2,3,4\end{array}$ & & & & & $87,902,753$ \\
\hline \multirow[t]{6}{*}{ Other Asia } & SEAR & Indonesia & $249,865,631$ & $49 \%$ & 7.00 & $35,695,090$ \\
\hline & WPR & Mongolia & $2,839,073$ & $31 \%$ & 10.5 & 270,388 \\
\hline & SEAR & India & $1,252,139,596$ & $72 \%$ & 23.0 & $38,108,596^{a}$ \\
\hline & WPR & China & $1,357,380,000$ & $55 \%$ & 10.4 & $71,784,519^{a}$ \\
\hline & $\begin{array}{l}\text { Total other } \\
\text { Asia }\end{array}$ & & & & & $145,858,593$ \\
\hline & $\begin{array}{l}\text { Total Asia } \\
\text { excluding } \\
\text { Pakistan. }\end{array}$ & & & & & $221,370,693$ \\
\hline \multicolumn{7}{|l|}{ Eurasia } \\
\hline & EUR & Kazakhstan & & & & \\
\hline & EUR & Kyrgyzstan & & & & \\
\hline & EUR & $\begin{array}{l}\text { Russian } \\
\text { Federation }\end{array}$ & & & & \\
\hline & EUR & Turkmenistan & & & & \\
\hline & EUR & Tajikistan & & & & \\
\hline & EUR & Uzbekistan & & & & \\
\hline & Total Eurasia & & $898,926,561$ & & 10.5 & $85,612,053$ \\
\hline \multicolumn{7}{|l|}{ Africa } \\
\hline \multicolumn{7}{|l|}{ SADC } \\
\hline & AFR & $\begin{array}{l}\text { Democratic } \\
\text { Republic of } \\
\text { the Congo }\end{array}$ & $67,513,677$ & $66 \%$ & 9.5 & \\
\hline & AFR & Angola & $21,471,618$ & $41 \%$ & 9.5 & \\
\hline & AFR & Zambia & $14,538,640$ & & 9.5 & \\
\hline & AFR & Malawi & $16,362,567$ & & 9.5 & \\
\hline & AFR & Tanzania & $49,253,126$ & & 9.5 & \\
\hline & AFR & Mozambique & $25,833,752$ & & 9.5 & \\
\hline & AFR & Zimbabwe & $14,149,648$ & & 9.5 & \\
\hline
\end{tabular}




\begin{tabular}{|c|c|c|c|c|c|c|}
\hline $\begin{array}{l}\text { Geographic } \\
\text { area }\end{array}$ & WHO region & Country & $\begin{array}{l}\text { Human } \\
\text { population } \\
\text { (estimated) }\end{array}$ & $\begin{array}{l}\text { Percentage } \\
\text { rural }\end{array}$ & $\begin{array}{l}\text { Human/ } \\
\text { dog ratio }\end{array}$ & $\begin{array}{l}\text { Dog population } \\
\text { (estimated) }\end{array}$ \\
\hline & AFR & Botswana & $2,021,144$ & & 9.5 & \\
\hline & AFR & Namibia & $2,303,315$ & & 9.5 & \\
\hline & AFR & South Africa & $52,981,991$ & & 9.5 & \\
\hline & AFR & Swaziland & $1,249,514$ & & 9.5 & \\
\hline & AFR & Madagascar & $22,924,851$ & & 9.5 & \\
\hline & AFR & Lesotho & $2,074,465$ & & 9.5 & \\
\hline & Total SADC & & $292,678,308$ & & 9.5 & $30,808,243$ \\
\hline \multicolumn{7}{|l|}{ North Africa } \\
\hline & EMR & Morocco & $33,008,150$ & & 31.2 & \\
\hline & EMR & Algeria & $39,208,194$ & & 31.2 & \\
\hline & EMR & Tunesia & $10,886,500$ & & 31.2 & \\
\hline & EMR & Libya & $6,201,521$ & & 31.2 & \\
\hline & EMR & Egypt & $82,056,378$ & & 31.2 & \\
\hline & EMR & $\begin{array}{l}\text { Western } \\
\text { Sahara }\end{array}$ & 500,000 & & 31.2 & \\
\hline & EMR & $\begin{array}{l}\text { Sudan (+ } \\
\text { south) }\end{array}$ & $37,964,306$ & & 31.2 & \\
\hline & $\begin{array}{l}\text { Total North } \\
\text { Africa }\end{array}$ & & $209,825,049$ & & 31.2 & $6,725,162$ \\
\hline \multicolumn{7}{|l|}{ West Africa } \\
\hline & AFR & Benin & $10,323,474$ & & 16.8 & \\
\hline & AFR & Burkina Faso & $16,934,839$ & & 16.8 & \\
\hline & AFR & Cape Verde & 498,897 & & 16.8 & \\
\hline & AFR & Ivory Coast & $20,316,086$ & & 16.8 & \\
\hline & AFR & Gambia & $1,849,285$ & & 16.8 & \\
\hline & AFR & Ghana & $25,904,598$ & & 16.8 & \\
\hline & AFR & Guinea & $11,745,189$ & & 16.8 & \\
\hline & AFR & $\begin{array}{l}\text { Guinea- } \\
\text { Bissau }\end{array}$ & $1,704,255$ & & 16.8 & \\
\hline & AFR & Liberia & $4,294,077$ & & 16.8 & \\
\hline & AFR & Mali & $15,301,650$ & & 16.8 & \\
\hline & AFR & Niger & $17,831,270$ & & 16,8 & \\
\hline & AFR & Nigeria & $173,615,345$ & & 16.8 & \\
\hline & AFR & Senegal & $14,133,280$ & & 16.8 & \\
\hline & AFR & Sierra Leone & $6,092,075$ & & 16.8 & \\
\hline & AFR & Togo & $6,816,982$ & & 16.8 & \\
\hline & $\begin{array}{l}\text { Total West } \\
\text { Africa }\end{array}$ & & $327,361,302$ & & 16.8 & $19,485,792$ \\
\hline \multicolumn{7}{|l|}{ Other Africa } \\
\hline & AFR & Uganda & $37,578,876$ & & 9.5 & $3,955,671$ \\
\hline & AFR & Gabon & $1,671,711$ & & 16.8 & 99,507 \\
\hline & AFR & Nigeria & $173,615,345$ & & 16.8 & $10,334,247$ \\
\hline & AFR & $\begin{array}{l}\text { Equatorial } \\
\text { Guinea }\end{array}$ & 757,014 & & 16.8 & 45,060 \\
\hline & AFR & Chad & $12,825,314$ & & 16.8 & 763,412 \\
\hline & AFR & Rwanda & $11,776,522$ & & 9.5 & $1,239,634$ \\
\hline
\end{tabular}




\begin{tabular}{|c|c|c|c|c|c|c|}
\hline $\begin{array}{l}\text { Geographic } \\
\text { area }\end{array}$ & WHO region & Country & $\begin{array}{l}\text { Human } \\
\text { population } \\
\text { (estimated) }\end{array}$ & $\begin{array}{l}\text { Percentage } \\
\text { rural }\end{array}$ & $\begin{array}{l}\text { Human/ } \\
\text { dog ratio }\end{array}$ & $\begin{array}{l}\text { Dog population } \\
\text { (estimated) }\end{array}$ \\
\hline & AFR & Burundi & $10,162,532$ & & 16.8 & 604,913 \\
\hline & AFR & $\begin{array}{l}\text { Republic of } \\
\text { Congo }\end{array}$ & $4,447,632$ & & 9.5 & 468,172 \\
\hline & AFR & Ethiopia & $94,100,756$ & & 31.2 & $3,016,050$ \\
\hline & AFR & Mauretania & $3,889,880$ & & 31.2 & 124,676 \\
\hline & AFR & Kenya & $44,353,691$ & & 9.5 & $4,668,810$ \\
\hline & EMR & Somalia & $10,495,583$ & & 31.2 & 336,397 \\
\hline & AFR & $\begin{array}{l}\text { Central } \\
\text { African } \\
\text { Republic }\end{array}$ & $4,616,417$ & & 16.8 & 274,787 \\
\hline & AFR & Eritrea & $6,333,135$ & & 31.2 & 202,985 \\
\hline & AFR & Cameroon & $22,253,959$ & & 16.8 & $1,324,640$ \\
\hline & $\begin{array}{l}\text { Total other } \\
\text { Africa }\end{array}$ & & & & & $27,458,959$ \\
\hline $\begin{array}{l}\text { Total Africa } \\
\text { excluding } \\
\text { North } \\
\text { Africa and } \\
\text { Somalia }\end{array}$ & & & & & & $77,416,599$ \\
\hline \multicolumn{7}{|l|}{$\begin{array}{l}\text { Other } \\
\text { EMRO }\end{array}$} \\
\hline & EMR & Afghanistan & $30,551,674$ & & 35.4 & 863,042 \\
\hline & EMR & Bahrain & $1,332,171$ & & 35.4 & 37,632 \\
\hline & EMR & Djibouti & 872,932 & & 35.4 & 24,659 \\
\hline & EMR & Iran & $77,447,168$ & & 35.4 & $2,187,773$ \\
\hline & EMR & Iraq & $33,417,476$ & & 35.4 & 943,996 \\
\hline & EMR & Jordan & $6,459,000$ & & 35.4 & 182,458 \\
\hline & EMR & Kuwait & $3,368,572$ & & 35.4 & 95,157 \\
\hline & EMR & Lebanon & $4,467,390$ & & 35.4 & 126,197 \\
\hline & EMR & Palestine & $4,169,506$ & & 35.4 & 117,783 \\
\hline & EMR & Oman & $3,632,444$ & & 35.4 & 102,611 \\
\hline & EMR & Saudi Arabia & $28,828,870$ & & 35.4 & 814,375 \\
\hline & EMR & $\begin{array}{l}\text { Syrian Arab } \\
\text { Republic }\end{array}$ & $22,845,550$ & & 35.4 & 645,355 \\
\hline & EMR & $\begin{array}{l}\text { United Arab } \\
\text { Emirates }\end{array}$ & $9,346,129$ & & 35.4 & 264,015 \\
\hline & EMR & Yemen & $24,407,381$ & & 35.4 & 689,474 \\
\hline & $\begin{array}{l}\text { Total EMR } \\
\text { including } \\
\text { North Africa, } \\
\text { Pakistan, } \\
\text { Somalia and } \\
\text { other EMR } \\
\text { countries }\end{array}$ & & & & & $26,546,739$ \\
\hline Grand total & & & & & & $410,946,084$ \\
\hline
\end{tabular}

Adapted from K. Hampson (personal communication, 2014) using World population statistics 2010 at www.

worldpopulationstatistiscs.com and expanding on the list of countries eligible for GAVI support, 2014 (www. gavialliance. org/supportapply/countries-eligible-for-support). AFR, African region; EMR, East Mediterranean region; EMRO, Eastern Mediterranean Regional Office; EUR, European (Asian portion) Region; SADC, Southern Africa Development Community; SEAR, South East Asia Region; WHO, World Health Organization; WPR, West Pacific Region. 


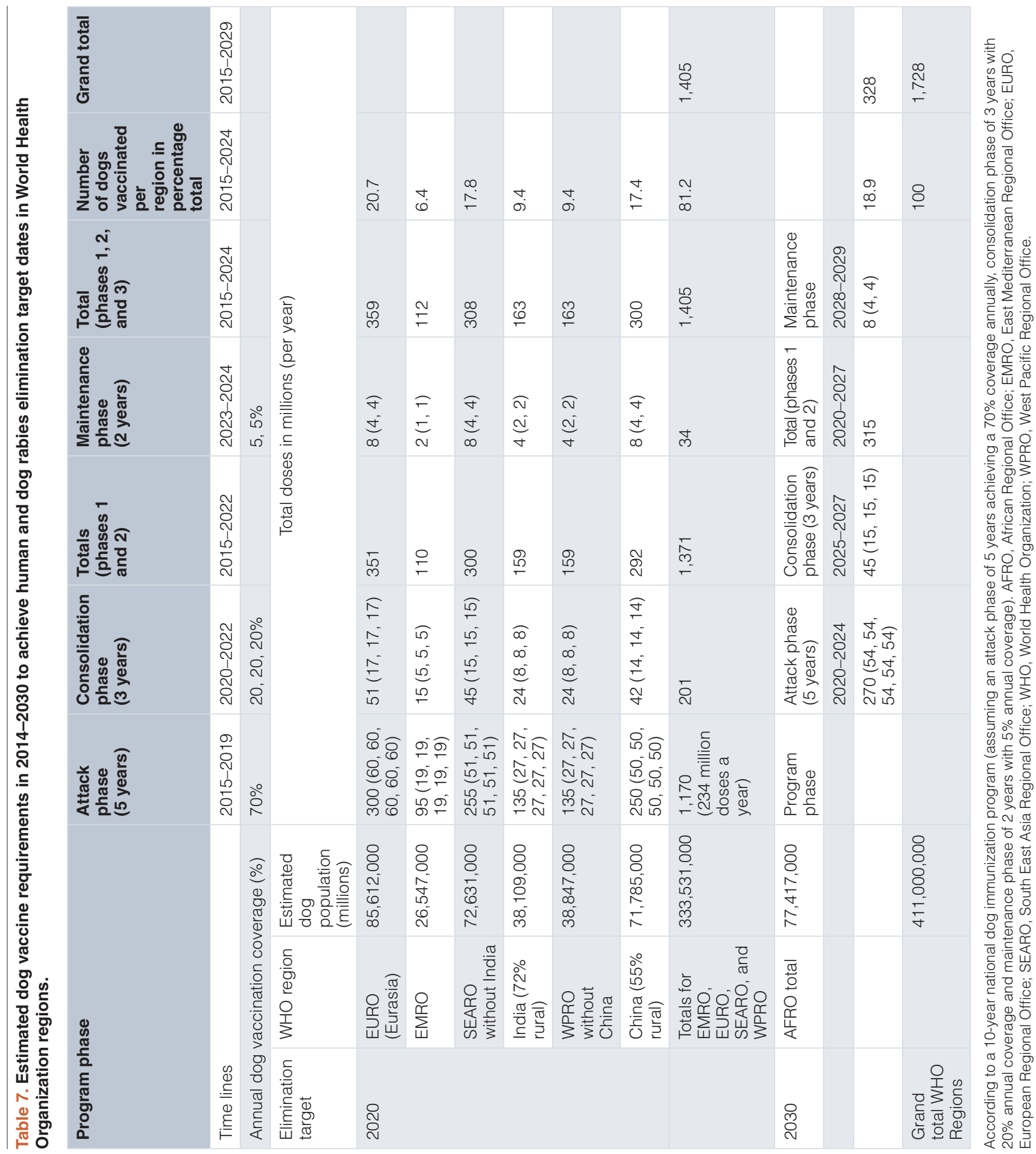


WHO regions, the attack phase extends from 2015 to 2019; the consolidation phase from 2020 to 2022; and the maintenance phase from 2023 to 2024, as the target date for human rabies elimination here is 2020. Many countries in the above listed WHO regions particularly the Southeast Asia and Western Pacific regions which carry a large part of the global human rabies burden have committed themselves to achieve the goal of human rabies elimination by 2020 and already scaled-up their dog and human rabies control activities (e.g Philippines, Sri Lanka, Thailand, Vietnam and parts of Indonesia, India \& China). For the African Region, the attack phase extends from 2020 to 2024; the consolidation phase from 2025 to 2027; and the maintenance phase from 2028 to 2029, as the target date for human rabies elimination here is 2030. The African region particularly sub-Saharan Africa will benefit from the full 10 year program plus preparatory time as the number of countries with experience of large-scale dog rabies immunization campaigns is comparatively small.

Based on these estimates, almost 1.3 billion doses (more than 260 million doses annually including a $10 \%$ wastage rate) are needed from 2015 to 2019 for the attack phase in Asia and the Middle East. This is a conservative figure, as human populations of urban centers of China and India, which have almost a billion people and associated large dog populations, were excluded from this computation. In India, a special rabies control program targets major cities $^{88}$. In large Chinese cities, dog rabies prevalence is lower, but dog ownership laws (though somewhat relaxed recently and often difficult to enforce) may remain quite strict ${ }^{89}$. In addition, 560 million doses are required from 2020 to 2024 (about 110 million doses annually) for the consolidation phase in these areas to initiate and conduct programs in Africa and maintain freedom in previously liberated areas. This means providing during the period of 2015-2019, on an annual basis, five times more dog vaccine to rural India and China, three times more for Eurasia, and two times more than currently used for the Eastern Mediterranean Region as well as five times more to the entire of Africa during the period of 2020-2024. Given the other existing priority market requirements, quantities needed in the short term (2015-2019) are likely to exceed major manufacturers' capacities of scaling-up. In addition, as almost $50 \%$ of these dog vaccine doses are needed in South, South Eastern, and Eastern Asian countries, especially in China and India, current procurement mechanisms for pure, potent, safe, and efficacious vaccines, mostly involving Northern Hemisphere manufacturers' production units, will not be acceptable by all.

Besides mass dog vaccination, to achieve the concomitant goal of human rabies elimination by 2030, international organizations must also support RIG manufacturing (particularly in developing countries), fast-track the addition of new vaccines to the WHO list of pre-qualified rabies vaccines, and invest in production of new, safer, and more affordable biologics for passive immunization $^{51,78,90}$.

Together with national public health authorities, these organizations must strongly discourage the unnecessary administration of very large and inappropriate numbers of PEP, which contribute to creating shortages in areas where these rabies biologics are truly needed (Table 8).

Concerning dog rabies vaccines, their sustained availability at the ground level has repeatedly been shown to be essential to the initiation of dog rabies control activities ${ }^{85}$. Essential steps to effectively increase veterinary rabies vaccine production to achieve humandog-mediated rabies elimination by 2030 must be seriously considered by international organizations and vaccine manufacturers supporting this goal. These steps include accelerating technology transfer to Africa and Asia and redirecting some existing human rabies vaccine manufacturing capacities toward canine vaccine production, as proposed more than 30 years ago by a joint Rockefeller/WHO initiative ${ }^{91}$. Similarly, GAVI support of human rabies vaccines might allow those eligible governments to use any conserved resources directed to veterinary public health, as begun regionally in the Americas in the 1980s. Comparatively modest investment in canine vaccination programs is predicted to have major cost- effective outcomes for the human rabies burden, even in some of the most severely affected areas ${ }^{92}$.

\section{Future vision}

Viral taxonomy may continue to adjust subjectively to changing times, differing philosophies, and bio-political pressure, yet regardless of the specific etiological names responsible for this disease, the moniker for rabies will remain. Theories on lyssavirus and host co-evolution will be complemented by methodological improvements and pathogen discovery. With enhanced, de-centralized laboratory-based surveillance and focused detection efforts, additional lyssavirus species and host shifts are expected. Stockpiling of vaccine and RIG, attention to existing recommendations, and careful risk assessments will increase the use of pre-exposure vaccination, maximize appropriate use of biologics in those truly exposed, and reduce PEP failures. Eventual application of the growing knowledge base on rabies pathogenetic mechanisms, pronounced intensive clinical skills in managing encephalitis, and the abilities to intervene with combinations of biologics and anti-viral drugs will gradually result in additional rabies survivors in human and veterinary medicine without losing the critical focus upon disease prevention. Ideally, under a progressive global business plan (with the minimum application of estimated biologics to the populations at risk, new champions, and dedicated sponsorships without vaccination fatigue), human rabies mediated by dogs should be eliminated in Latin America over the next 5 years, in Asia within a decade, and in Africa by 2030. Although 


\begin{tabular}{|c|c|c|c|c|c|c|}
\hline $\begin{array}{l}\text { Geographical } \\
\text { cluster }\end{array}$ & $\begin{array}{l}\text { World Health } \\
\text { Organization } \\
\text { region }\end{array}$ & $\begin{array}{l}\text { Human } \\
\text { populations }\end{array}$ & $\begin{array}{l}\text { PEP per } \\
\text { million people } \\
\text { (Total PEP } \\
\text { administered } \\
\text { per cluster) }\end{array}$ & $\begin{array}{l}\text { Exposures per } \\
\text { million (Total } \\
\text { exposures) }\end{array}$ & $\begin{array}{l}\text { Number } \\
\text { of non- } \\
\text { exposed } \\
\text { humans } \\
\text { receiving } \\
\text { PEP per } \\
\text { million }\end{array}$ & $\begin{array}{l}\text { Percentage of } \\
\text { non-exposed } \\
\text { humans } \\
\text { receiving PEP }\end{array}$ \\
\hline \multicolumn{7}{|l|}{ Asia } \\
\hline Total Asia 2 & WP and SEA & $\begin{array}{l}239,987,963, \\
\text { about } 240 \text { million }\end{array}$ & $4,764(1,143,377)$ & $3,195(766,842)$ & 1,569 & 0.33 \\
\hline Total Asia 3 & SEA & $\begin{array}{l}367,288,960 \\
\text { about } 367 \text { million }\end{array}$ & $914(335,740)$ & $667(244,767)$ & 247 & 0.27 \\
\hline Total Asia 4 & SEA and WP & $\begin{array}{l}\text { 185,887,076, } \\
\text { about } 186 \text { million }\end{array}$ & $4,638(862,641)$ & $1,413(262,841)$ & 3,225 & 0.70 \\
\hline Subtotal & & & $2,341,758$ & $(1,274,540)$ & & \\
\hline Total other Asia & $\begin{array}{l}\text { Indonesia, China, } \\
\text { India }\end{array}$ & $\begin{array}{l}2,859,385,227 \\
\text { about } 2.8 \text { billion }\end{array}$ & $\begin{array}{l}8,183 \\
(23,395,261)\end{array}$ & $\begin{array}{l}4,550 \\
(13,008,455)\end{array}$ & 3,633 & 0.44 \\
\hline Subtotal & & & $25,737,019$ & $(14,282,905)$ & & \\
\hline Eurasia & EUR & $\begin{array}{l}898,926,561 \\
\text { about } 899 \text { million }\end{array}$ & $748(672,177)$ & $289(259,650)$ & 495 & 0.66 \\
\hline \multicolumn{7}{|l|}{ Africa } \\
\hline SADC & AFR & $\begin{array}{l}292,678,308 \\
\text { about } 293 \text { million }\end{array}$ & $1,766(517,409)$ & $925(271,041)$ & 841 & 0.48 \\
\hline North Africa & EMR & $\begin{array}{l}\text { 20,982,504, } \\
\text { about } 21 \text { million }\end{array}$ & $1,917(402,632)$ & $930(195,237)$ & 987 & 0.51 \\
\hline West Africa & AFR & $\begin{array}{l}327,361,302, \\
\text { about } 327 \text { million }\end{array}$ & $1,071(350,374)$ & $790(258,341)$ & 281 & 0.26 \\
\hline Other Africa & AFR & $\begin{array}{l}438,878,367 \\
\text { about } 439 \text { million }\end{array}$ & $265(116,433)$ & $273(119,707)$ & -8 & -0.03 \\
\hline Subtotal & & & $1,386,848$ & 844,326 & & \\
\hline \multicolumn{7}{|l|}{ EMRO } \\
\hline & $\begin{array}{l}\text { Minus North } \\
\text { Africa and } \\
\text { Somalia }\end{array}$ & $\begin{array}{l}251,146,263, \\
\text { about } 251 \text { million }\end{array}$ & $932(233,883)$ & $465(116,785)$ & 467 & 0.50 \\
\hline
\end{tabular}

Adapted from 70. AFR, African region; EMR, East Mediterranean region; EMRO, Eastern Mediterranean Regional Office; EUR, European (Asian portion) Region; SADC, Southern Africa Development Community; SEA, South East Asia; WHO, World Health Organization; WP, West Pacific.

eradication is not the aim, given a diversity of wildlife reservoirs and a lack of strategies to break the chain of perpetuation among the Chiroptera, the time is long overdue to accomplish such other ambitious goals against an ancient and insidious but neglected killer.

Author contributions

All authors were involved in the writing of the manuscript and agreed to the final content.
Competing interests

The authors declare that they have no competing interests.

Grant information

The author(s) declared that no grants were involved in supporting this work.

\section{Acknowledgments}

The authors thank their many colleagues in academia, government, industry, and non-governmental organizations for research collaborations to date. 
1. F Walker PJ, Firth C, Widen SG, et al:: Evolution of genome size and complexity in the rhabdoviridae. PLoS Pathog. 2015; 11(2): e1004664. PubMed Abstract | Publisher Full Text | Free Full Text | F1000 Recommendation

2. Afonso CL, Amarasinghe GK, Bányai K, et al:: Taxonomy of the order Mononegavirales: update 2016. Arch Virol. 2016; 161(8): 2351-60. PubMed Abstract | Publisher Full Text | Free Full Text

3. Van Regenmortel $\mathrm{MH}$, Burke DS, Calisher $\mathrm{CH}$, et al:: A proposal to change existing virus species names to non-Latinized binomials. Arch Virol. 2010; 155(11): 1909-19.

PubMed Abstract | Publisher Full Text

4. Van Regenmortel $\mathrm{MH}$, Ackermann $\mathrm{HW}$, Calisher $\mathrm{CH}$, et al:: Virus species polemics: 14 senior virologists oppose a proposed change to the ICTV definition of virus species. Arch Virol. 2013; 158(5): 1115-9. PubMed Abstract | Publisher Full Text

5. Aréchiga Ceballos N, Vázquez Morón S, Berciano JM, et al.: Novel lyssavirus in bat, Spain. Emerg Infect Dis. 2013; 19(5): 793-5. PubMed Abstract | Publisher Full Text | Free Full Text

6. F Gunawardena PS, Marston DA, Ellis RJ, et al:: Lyssavirus in Indian Flying Foxes, Sri Lanka. Emerg Infect Dis. 2016; 22(88): 1456-9. PubMed Abstract | Publisher Full Text | Free Full Text | F1000 Recommendation

7. Badrane $\mathrm{H}$, Bahloul $\mathrm{C}$, Perrin $\mathrm{P}$, et al.: Evidence of two Lyssavirus phylogroups with distinct pathogenicity and immunogenicity. J Virol. 2001; 75(7): 3268-76. PubMed Abstract | Publisher Full Text | Free Full Text

8. Horton DL, Banyard AC, Marston DA, et al:: Antigenic and genetic characterization of a divergent African virus, Ikoma lyssavirus. J Gen Virol. 2014; 95(Pt 5): 1025-32. PubMed Abstract | Publisher Full Text | Free Full Text

9. Dietzgen $\mathrm{RG}$, Calisher $\mathrm{CH}$, Kurath $\mathrm{G}$, et al:: Family Rhabdoviridae. In: King $\mathrm{AMQ}$, Adams MJ, Carstens EB, Lefkowitz EL, editors. Virus Taxonomy: 9th report of the International Committee on Taxonomy of Viruses. Oxford, UK: Elsevier; 2011 686-714.

Publisher Full Text

10. World Health Organization: Expert consultation on rabies. Second report. WHO Technical Report Series; no. 982. Geneva, Switzerland: World Health Organization; 2013; 7 .

Reference Source

11. Kgaladi J, Wright $\mathrm{N}$, Coertse J, et al.: Diversity and epidemiology of Mokola virus. PLoS Negl Trop Dis. $2013 ; 7$ (10): e2511.

PubMed Abstract | Publisher Full Text | Free Full Text

12. Badrane $\mathrm{H}$, Tordo $\mathrm{N}$ : Host switching in Lyssavirus history from the Chiroptera to the Carnivora orders. J Virol. 2001; 75(17): 8096-104. PubMed Abstract | Publisher Full Text | Free Full Text

13. Davis PL, Bourhy H, Holmes EC: The evolutionary history and dynamics of bat rabies virus. Infect Genet Evol. 2006; 6(6): 464-73.

PubMed Abstract | Publisher Full Text

14. Woelk $\mathrm{CH}$, Holmes EC: Reduced positive selection in vector-borne RNA viruses. Mol Biol Evol. 2002; 19(12): 2333-6. PubMed Abstract | Publisher Full Text

15. Kuzmina NA, Kuzmin IV, Ellison JA, et al:: A reassessment of the evolutionary timescale of bat rabies viruses based upon glycoprotein gene sequences. Virus Genes. 2013; 47(2): 305-10. PubMed Abstract | Publisher Full Text

16. Streicker DG, Altizer SM, Velasco-Villa A, et al.: Variable evolutionary routes to host establishment across repeated rabies virus host shifts among bats. Proc Natl Acad Sci U S A. 2012; 109(48): 19715-20. PubMed Abstract | Publisher Full Text

17. Markotter W, Randles J, Rupprecht CE, et al.: Lagos bat virus, South Africa Emerg Infect Dis. 2006; 12(3): 504-6. PubMed Abstract | Free Full Text

18. Kuzmin IV, Niezgoda M, Franka R, et al.: Lagos bat virus in Kenya. J Clin Microbiol. 2008; 46(4): 1451-61.

PubMed Abstract | Publisher Full Text | Free Full Text

19. Streicker DG, Turmelle AS, Vonhof MJ, et al.: Host phylogeny constrains crossspecies emergence and establishment of rabies virus in bats. Science. 2010; 329(5992): 676-9.

PubMed Abstract | Publisher Full Text

20. Kuzmin IV, Shi M, Orciari LA, et al:: Molecular inferences suggest multiple host shifts of rabies viruses from bats to mesocarnivores in Arizona during 2001-2009. PLoS Pathog. 2012; 8(6): e1002786. PubMed Abstract | Publisher Full Text

21. Hughes GJ, Orciari LA, Rupprecht CE: Evolutionary timescale of rabies virus adaptation to North American bats inferred from the substitution rate of the nucleoprotein gene. J Gen Virol. 2005; 86(Pt 5): 1467-74 PubMed Abstract | Publisher Full Text

22. Nadin-Davis SA, Feng $Y$, Mousse D, et al:: Spatial and temporal dynamics of rabies virus variants in big brown bat populations across Canada: footprints of an emerging zoonosis. Mol Ecol. 2010; 19(10): 2120-36.

PubMed Abstract | Publisher Full Text
23. F Wertheim JO, Kosakovsky Pond SL: Purifying selection can obscure the ancient age of viral lineages. Mol Biol Evol. 2011; 28(12): 3355-65. PubMed Abstract | Publisher Full Text | Free Full Text | F1000 Recommendation

24. Wertheim JO, Chu DK, Peiris JS, et al:: A case for the ancient origin of coronaviruses. J Virol. 2013; 87(12): 7039-45.

PubMed Abstract | Publisher Full Text | Free Full Text

25. Duchêne S, Duchêne D, Holmes EC, et al:: The Performance of the DateRandomization Test in Phylogenetic Analyses of Time-Structured Virus Data. Mol Biol Evol. 2015; 32(7): 1895-906.

PubMed Abstract | Publisher Full Text

26. Ho SY, Lanfear R, Bromham L, et al.: Time-dependent rates of molecular evolution. Mol Ecol. 2011; 20(15): 3087-101.

PubMed Abstract | Publisher Full Text

27. Holmes EC: Complexities of Estimating Evolutionary Rates in Viruses. J Virol. 2016; 90(4): 2155

PubMed Abstract | Publisher Full Text | Free Full Text

28. Rupprecht CE, Turmelle A, Kuzmin IV: A perspective on lyssavirus emergence and perpetuation. Curr Opin Virol. 2011; 1(6): 662-70. PubMed Abstract | Publisher Full Text

29. Nadin-Davis SA, Real LA: Molecular phylogenetics of the lyssaviruses--insights from a coalescent approach. Adv Virus Res. 2011; 79: 203-38. PubMed Abstract | Publisher Full Text

30. Kuzmin IV, Tordo N: Genus Lyssavirus. In: Dietzgen RD, Kuzmin IV, editors. Rhabdoviruses: Molecular taxonomy, evolution, genomics, ecology, host-vector interactions, cytopathology and control. London, UK: Caister Academic Press; 2012; 37-57.

Reference Source

31. Eick GN, Jacobs DS, Matthee CA: A nuclear DNA phylogenetic perspective on the evolution of echolocation and historical biogeography of extant bats (chiroptera). Mol Biol Evol. 2005; 22(9): 1869-86. PubMed Abstract | Publisher Full Text

32. Simmons NB, Seymour KL, Habersetzer J, et al:: Primitive Early Eocene bat from Wyoming and the evolution of flight and echolocation. Nature. 2008; 451(7180): $818-21$

PubMed Abstract | Publisher Full Text

33. Arnason U, Adegoke JA, Gullberg A, et al:: Mitogenomic relationships of placental mammals and molecular estimates of their divergences. Gene. 2008; 421(1-2): 37-51.

PubMed Abstract | Publisher Full Text

34. Raup DM, Sepkoski JJ Jr: Mass extinctions in the marine fossil record. Science. 1982; 215(4539): 1501-3.

PubMed Abstract | Publisher Full Text

35. Aiewsakun $P$, Katzourakis A: Endogenous viruses: Connecting recent and ancient viral evolution. Virology. 2015; 479-480: 26-37. PubMed Abstract | Publisher Full Tex

36. F Chaves LB, Achkar SM, Silva Ade C, et al.: Monoclonal antibodies for characterization of rabies virus isolated from non-hematophagous bats in Brazil. J Infect Dev Ctries. 2015; 9(11): 1238-49.

PubMed Abstract | Publisher Full Text | F1000 Recommendation

37. OIE: Manual of Diagnostic Tests and Vaccines for Terrestrial Animals 2016 , chapter 2.1.17 rabies. (accessed 10/26/2016). Reference Source

38. Mallewa M, Vallely $\mathrm{P}$, Faragher $\mathrm{B}$, et al.: Viral CNS infections in children from a malaria-endemic area of Malawi: a prospective cohort study. Lancet Glob Health. 2013; 1(3): e153-60.

PubMed Abstract | Publisher Full Text | Free Full Text

39. Dato VM, Campagnolo ER, Long J, et al.: A Systematic Review of Human Bat Rabies Virus Variant Cases: Evaluating Unprotected Physical Contact with Claws and Teeth in Support of Accurate Risk Assessments. PLoS One. 2016; 11(7): e0159443.

PubMed Abstract | Publisher Full Text | Free Full Text

40. Boland TA, McGuone D, Jindal J, et al.: Phylogenetic and epidemiologic evidence of multiyear incubation in human rabies. Ann Neurol. 2014; 75(1): $155-60$.

PubMed Abstract | Publisher Full Text | Free Full Text

41. Savadogo M, Boushab MB: [Rabies in children: an often unknown risk among populations at risk]. Med Sante Trop. 2015; 25(2): 222-4. PubMed Abstract | Publisher Full Text

42. F Zhou H, Zhu W, Zeng J, et al.: Probable Rabies Virus Transmission through Organ Transplantation, China, 2015. Emerg Infect Dis. 2016; 22(8): 1348-52. PubMed Abstract | Publisher Full Text | Free Full Text | F1000 Recommendation

43. F Chang SS, Tsai HJ, Chang FY, et al:: Government Response to the Discovery of a Rabies Virus Reservoir Species on a Previously Designated Rabies-Free Island, Taiwan, 1999-2014. Zoonoses Public Health. 2016; 63(5): 396-402.

PubMed Abstract | Publisher Full Text | F1000 Recommendation

44. F Sinclair JR, Wallace RM, Gruszynski K, et al.: Rabies in a Dog Imported from 
Egypt with a Falsified Rabies Vaccination Certificate--Virginia, 2015. MMWR Morb Mortal Wkly Rep. 2015; 64(49): 1359-62.

PubMed Abstract | Publisher Full Text | F1000 Recommendation

45. Rupprecht CE, Nagarajan T, Ertl H: Current Status and Development of Vaccine and Other Biologics for Human Rabies Prevention. Expert Rev Vaccines. 2016; 15(6): 731-49.

PubMed Abstract | Publisher Full Text

46. F Giesen A, Gniel D, Malerczyk C: $\mathbf{3 0}$ Years of rabies vaccination with Rabipur: a summary of clinical data and global experience. Expert Rev Vaccines. 2015; 14(3): 351-67.

PubMed Abstract | Publisher Full Text | F1000 Recommendation

47. Pichon S, Guinet-Morlot F, Minutello M, et al:: A serum-free, purified vero cell rabies vaccine is safe and as immunogenic as the reference vaccine Verorab for pre-exposure use in healthy adults: results from a randomized controlled phase-II trial. Vaccine. 2013; 31(18): 2295-301.

PubMed Abstract | Publisher Full Text

48. Rupprecht CE, Briggs D, Brown CM, et al.: Use of a reduced (4-dose) vaccine schedule for postexposure prophylaxis to prevent human rabies: recommendations of the advisory committee on immunization practices. MMWR Recomm Rep. 2010; 59(RR-2): 1-9.

PubMed Abstract

49. F Bharti OK, Madhusudana SN, Gaunta PL, et al:: Local infiltration of rabies mmunoglobulins without systemic intramuscular administration: An alternative cost effective approach for passive immunization against rabies. Hum Vaccin Immunother. 2016; 12(3): 837-42.

PubMed Abstract | Publisher Full Text | Free Full Text | F1000 Recommendation

50. Bose A, Munshi R, Tripathy RM, et al:: A randomized non-inferiority clinical study to assess post-exposure prophylaxis by a new purified vero cell rabies vaccine (Rabivax-S) administered by intramuscular and intradermal routes. Vaccine. 2016; 34(40): 4820-6. PubMed Abstract | Publisher Full Tex

51. F De Benedictis P, Minola A, Rota Nodari E, et al:: Development of broadspectrum human monoclonal antibodies for rabies post-exposure prophylaxis. EMBO Mol Med. 2016; 8(4): 407-21.

PubMed Abstract | Publisher Full Text | Free Full Text | F1000 Recommendation

52. Madhusudana SN, Ashwin BY, Sudarshan S: Feasibility of reducing rabies immunoglobulin dosage for passive immunization against rabies: results of In vitro and In vivo studies. Hum Vaccin Immunother. 2013; 9(9): 1914-7. PubMed Abstract | Publisher Full Text | Free Full Text

53. Morimoto $\mathrm{K}$, Khawplod $\mathrm{P}$, Sato $\mathrm{Y}$, et al:: Rabies vaccination at a virus-inoculated site as an alternative option to rabies immunoglobulin. Arch Virol. 2016; 161(9): 2537-41.

PubMed Abstract | Publisher Full Text

54. Ren J, Yao L, Sun J, et al:: Zagreb regimen, an abbreviated intramuscular schedule for rabies vaccination. Clin Vaccine Immunol. 2015; 22(1): 1-5. PubMed Abstract | Publisher Full Text | Free Full Text

55. Reveneau E, Cottin $P$, Rasuli A: Two decades of pharmacovigilance and clinica experience with highly purified rabies immunoglobulin $F\left(a b^{\prime}\right)_{2}$ fragments. Expert Rev Vaccines. 2016; 1-15 PubMed Abstract | Publisher Full Tex

56. Wilde $\mathrm{H}$, Lumlertdacha $\mathrm{B}$, Meslin FX, et al.: Worldwide rabies deaths prevention--A focus on the current inadequacies in postexposure prophylaxis of animal bite victims. Vaccine. 2016; 34(2): 187-9. PubMed Abstract | Publisher Full Tex

57. Wongsaroj $\mathrm{P}$, Udomchaisakul $\mathrm{P}$, Tepsumethanon $\mathrm{S}$, et al.: Rabies neutralizing antibody after 2 intradermal doses on days 0 and 21 for pre-exposure prophylaxis. Vaccine. 2013; 31(13): 1748-51.

PubMed Abstract | Publisher Full Text

58. Zhang $Y$, Zhang S, Li L, et al.: Ineffectiveness of rabies vaccination alone for post-exposure protection against rabies infection in animal models. Antiviral Res. 2016; 135: 56-61.

PubMed Abstract | Publisher Full Text

59. Warrell MJ: The dilemma of managing human rabies encephalitis. Trop Med Int Health. 2016; 21(4): 456-7.

PubMed Abstract | Publisher Full Text

60. Appolinario CM, Jackson AC: Antiviral therapy for human rabies. Antivir Ther. 2015; 20(1): 1-10. PubMed Abstract | Publisher Full Text

61. F Willoughby RE Jr, Tieves KS, Hoffman GM, et al.: Survival after treatment of rabies with induction of coma. N Engl J Med. 2005; 352(24): 2508-14. PubMed Abstract | Publisher Full Text | F1000 Recommendation

62. Zeiler FA, Jackson AC: Critical Appraisal of the Milwaukee Protocol for Rabies: This Failed Approach Should Be Abandoned. Can J Neurol Sci. 2016; 43(1): $44-51$.

PubMed Abstract | Publisher Full Text

63. Manoj S, Mukherjee A, Johri S, et al.: Recovery from rabies, a universally fatal disease. Mil Med Res. 2016; 3: 21.

PubMed Abstract | Publisher Full Text | Free Full Text

64. Mahadevan A, Suja MS, Mani RS, et al:: Perspectives in Diagnosis and Treatment of Rabies Viral Encephalitis: Insights from Pathogenesis. Neurotherapeutics. 2016; 13(3): 477-92.

PubMed Abstract | Publisher Full Text | Free Full Text
65. Pan American Health Organization: Elimination of dog-transmitted human rabies is by 2015 within reach. PAHO, 2013; (accessed 09/27/2016).

Reference Source

66. World Health Organization: Sustaining the drive to overcome the global impact of neglected tropical diseases, second report on neglected tropical diseases. World Health Organization, Geneva, 2012.

Reference Source

67. World Health Organization: Accelerating work to overcome the global impact of neglected tropical diseases: a roadmap for implementation. Executive summary. World Health Organization. Geneva, 2012

Reference Source

68. World Health Organization: Global elimination of dog-mediated human rabies. Report of the Global Conference, 10-11 December 2015. World Health Organization and World Animal Health Organization, 2016. WHO_HTM_NTD_NZD_ 2016.02.

Reference Source

69. World Health Organization: Resolution WHA66.12 on NTD adopted by the World Health Assembly on 27 May 2013. (accessed 10/12/2016). Reference Source

70. Hampson K, Coudeville L, Lembo T, et al.: Estimating the global burden of endemic canine rabies. PLoS Negl Trop Dis. 2015: 9(4): e0003709. PubMed Abstract | Publisher Full Text | Free Full Text

71. Dehove A: OIE regional vaccine banks. Presentation made to the Middle East \& Eastern Europe Rabies Expert Bureau Meeting (MEEREB) 7-9 April 2015, Lyon, France; (accessed 09/27/2016). Reference Source

72. OIE: Regional Vaccine Bank for Asia provides 50,000 rabies vaccine doses to Lao PDR. OIE Press releases, 28 September 2012; (accessed 09/27/2016). Reference Source

73. Abela-Ridder B, Martin S, Gongal G, et al:: Rabies vaccine stockpile: fixing the supply chain. Bull World Health Organ. 2016; 94(9): 635-635A. PubMed Abstract | Publisher Full Text | Free Full Text

74. World Health Organization: Human and dog rabies vaccines and immunoglobulins report of a WHO/OIE meeting. Geneva 12-13 October 2015. WHO/HTM/NTD/NZD/2015.11.

Reference Source

75. CDC: Compendium of animal rabies prevention and control. NASPHV Recommendations and Report, MMWR. 2011; 60(6): 1-14. Reference Source

76. Schneider MC, Belotto A, Adé MP, et al:: Current status of human rabies transmitted by dogs in Latin America. Cad Saude Publica. 2007; 23(9): 2049-63. PubMed Abstract | Publisher Full Text

77. Vigilato MA, Clavijo A, Knobl T, et al.: Progress towards eliminating canine rabies: policies and perspectives from Latin America and the Caribbean. Philos Trans $R$ Soc Lond B Biol Sci. 2013; 368(1623): 20120143. PubMed Abstract | Publisher Full Text | Free Full Text

78. World Health Organization: Vaccine standards. 2016; (accessed 10/26/2016) Reference Source

79. Partners For Rabies Prevention: Human:dog ratios obtained from detailed studies in a range of rural and urban settings. In Canines rabies blueprint. (accessed 10/06/2016) Reference Source

80. Knobel DL, Cleaveland S, Coleman PG, et al.: Re-evaluating the burden of rabies in Africa and Asia. Bull World Health Organ. 2005; 83(5): 360-8. PubMed Abstract | Free Full Text

81. Sudarshan MK, Madhusudana SN, Mahendra BJ, et al: Assessing the burden of human rabies in India: results of a national multi-center epidemiological survey. Int J Infect Dis. 2007; 11(1): 29-35.

PubMed Abstract | Publisher Full Text

82. Bögel K, Meslin FX: Economics of human and canine rabies elimination: guidelines for programme orientation. Bull World Health Organ. 1990; 68(3): $281-91$

PubMed Abstract | Free Full Text

83. FAO: Developing a stepwise approach for rabies prevention and control. $F A O /$ GARC workshop. FAO Animal Production and Health Proceedings, No 18, Rome, Italy. Reference Source

84. Partners For Rabies Prevention: Blueprint for dog rabies control. (accessed 10/06/2016) Reference Source

85. World Health Organization: Report of the 4th meeting of the international coordination group of the Gates Foundation/WHO project for human and dog rabies elimination in low-income countries. 19-21 October 2011 PieterMartizburg, KwaZuluNatal, South Africa. Geneva, World Health Organization, 2011; (accessed 10/06/2016) Reference Source

86. Zinsstag J, Dürr S, Penny MA, et al:: Transmission dynamics and economics of rabies control in dogs and humans in an African city. Proc Natl Acad Sci U S A. 2009; 106(35): 14996-5001.

PubMed Abstract | Publisher Full Text | Free Full Text

87. World Health Organization: Educate, vaccinate, eliminate: Achieving zero human deaths from dog-transmitted rabies by 2030 . Joint Statement World 
Health Organization (WHO), World Organisation for Animal Health (OIE), Food and Agriculture Organization of the United Nations (FAO), 28 September 2016 | Geneva; (accessed 10/26/2016).

Reference Source

88. NCDC: National Rabies Prevention \& Control Pilot Projects in Ahmedabad, Bangalore, Pune, Madurai and Delhi under the 11th five year plan [2007 - 2012] and National Rabies Control Programme under the 12th five year plan (2012-17). Zoonoses Section, National Centre for Disease Control (NCDC), Delhi, India.

89. Molloy A: China to crackdown on pet dogs. (accessed 10/13/2016) Reference Source

90. Müller T, Dietzschold B, Ertl H, et al: Development of a mouse monoclonal antibody cocktail for post-exposure rabies prophylaxis in humans. PLOS Neg Trop Dis. 2009; 3(11): e542.

PubMed Abstract | Publisher Full Text | Free Full Text

91. Halstead SB: Vaccines are forever. A short history of the Rockefeller Foundation/WHO Rabies Vaccine Production Technology Transfer Project. Presented at the occasion of the inauguration of VECOL rabies vaccine production unit, Bogota, Columbia. 1/25/2002; (accessed 1/23/2017). Reference Source

92. F Fitzpatrick MC, Shah HA, Pandey A, et al:: One Health approach to cost-effective rabies control in India. Proc Natl Acad Sci U S A. 2016; 113(51): 14574-81. PubMed Abstract | Publisher Full Text | Free Full Text | F1000 Recommendation

93. Hamilton PB, Teixeira MM Stevens JR: The evolution of Trypanosoma cruzi: the 'bat seeding' hypothesis. Trends Parasitol. 2012; 28(4): 136-41. PubMed Abstract | Publisher Full Text

94. F Mani RS, Anand AM, Madhusudana SN: Human rabies in India: an audit from a rabies diagnostic laboratory. Trop Med Int Health. 2016; 21(4): 556-63. PubMed Abstract | Publisher Full Text | F1000 Recommendation

95. Madhusudana SN, Subha S, Thankappan U, et al:: Evaluation of a direct rapid immunohistochemical test (dRIT) for rapid diagnosis of rabies in animals and humans. Virol Sin. 2012; 27(5): 299-302. PubMed Abstract | Publisher Full Text

96. Carrieri ML, Peixoto ZM, Paciencia ML, et al.: Laboratory diagnosis of equine rabies and its implications for human postexposure prophylaxis. $J$ Virol Methods. 2006; 138(1-2): 1-9. PubMed Abstract | Publisher Full Tex

97. F Léchenne M, Naïssengar K, Lepelletier A, et al: Validation of a Rapid Rabies Diagnostic Tool for Field Surveillance in Developing Countries. PLOS Negl Trop Dis. 2016; 10(10): e0005010. PubMed Abstract | Publisher Full Text | Free Full Text | F1000 Recommendation

98. F Eggerbauer E, de Benedictis P, Hoffmann B, et al.: Evaluation of Six Commercially Available Rapid Immunochromatographic Tests for the Diagnosis of Rabies in Brain Material. PLOS Negl Trop Dis. 2016; 10(6): e0004776.

PubMed Abstract | Publisher Full Text | Free Full Text | F1000 Recommendation

99. Ngoepe E, Fehlner-Gardiner C, Wandeler A, et al.: Antigenic characterisation of lyssaviruses in South Africa. Onderstepoort J Vet Res. 2014; 81(1) PubMed Abstract | Publisher Full Text

100. Pratt PD, Henschel K, Turabelidze G, et al:: Human Rabies - Missouri, 2014. MMWR Morb Mortal Wkly Rep. 2016; 65(10): 253-6. PubMed Abstract | Publisher Full Text

101. F Dacheux L, Larrous F, Lavenir R, et al:: Dual Combined Real-Time Reverse Transcription Polymerase Chain Reaction Assay for the Diagnosis of Lyssavirus Infection. PLoS Negl Trop Dis. 2016; 10(7): e0004812. PubMed Abstract | Publisher Full Text | Free Full Text | F1000 Recommendation
102. F Wasniewski M, Almeida I, Baur A, et al.: First international collaborative study to evaluate rabies antibody detection method for use in monitoring the effectiveness of oral vaccination programmes in fox and raccoon dog in Europe. J Virol Methods. 2016; 238: 77-85. PubMed Abstract | Publisher Full Text | F1000 Recommendation

103. F Brunker K, Marston DA, Horton DL, et al:: Elucidating the phylodynamics of endemic rabies virus in eastern Africa using whole-genome sequencing. Virus Evol. 2015; 1(1): vev011.

PubMed Abstract | Publisher Full Text | Free Full Text | F1000 Recommendation

104. Borucki MK, Chen-Harris H, Lao V, et al.: Ultra-deep sequencing of intra-host rabies virus populations during cross-species transmission. PLoS Negl Trop Dis. 2013; 7(11): e2555.

PubMed Abstract | Publisher Full Text | Free Full Text

105. F Tarantola A, Crabol Y, Mahendra BJ, et al.: Caring for patients with rabies in developing countries - the neglected importance of palliative care. Trop Med Int Health. 2016; 21(4): 564-7.

PubMed Abstract | Publisher Full Text | F1000 Recommendation

106. Willoughby RE Jr: Rabies: Rare Human Infection - Common Questions. Infect Dis Clin North Am. 2015; 29(4): 637-50. PubMed Abstract | Publisher Full Text

107. Pathak S, Horton DL, Lucas S, et al.: Diagnosis, management and post-mortem findings of a human case of rabies imported into the United Kingdom from India: a case report. Virol J. 2014; 11: 63 PubMed Abstract | Free Full Text

108. Xiang ZQ, Greenberg L, Ertl HC, et al.: Protection of non-human primates against rabies with an adenovirus recombinant vaccine. Virology. 2014; 450-451. 243-9.

PubMed Abstract | Publisher Full Text | Free Full Text

109. Huang CT, Li Z, Huang Y, et al:: Enhancement of blood-brain barrie permeability is required for intravenously administered virus neutralizing antibodies to clear an established rabies virus infection from the brain and prevent the development of rabies in mice. Antiviral Res. 2014; 110: 132-41. PubMed Abstract | Publisher Full Text | Free Full Text

110. Rodriguez JM, Marchicio J, López M, et al: PyNTTTTGT and CpG immunostimulatory oligonucleotides: effect on granulocyte/monocyte colonystimulating factor (GM-CSF) secretion by human $\mathrm{CD}^{+} 6^{+}$(NK and NKT) cells. PLoS One. 2015; 10(2): e0117484 PubMed Abstract | Publisher Full Text | Free Full Text

111. F Virojanapirom $P$, Lumlertdacha B, Wipattanakitchareon $A$, et al:: T-705 as a Potential Therapeutic Agent for Rabies. J Infect Dis. 2016; 214(3): 502-3. PubMed Abstract | Publisher Full Text | F1000 Recommendation

112. Lingappa UF, Wu X, Macieik A, et al:: Host-rabies virus protein-protein interactions as druggable antiviral targets. Proc Natl Acad Sci U S A. 2013; 110(10): E861-8. PubMed Abstract | Publisher Full Text | Free Full Text

113. F Gnanadurai $\mathrm{CW}, \mathrm{Fu} Z \mathrm{ZF}$ : CXCL10 and blood-brain barrier modulation in rabies virus infection. Oncotarget. 2016; 7(10): 10694-5. PubMed Abstract | Publisher Full Text | Free Full Text | F1000 Recommendation

114. Willoughby RE, Opladen T, Maier T, et al:: Tetrahydrobiopterin deficiency in human rabies. J Inherit Metab Dis. 2009; 32(1): 65-72. PubMed Abstract | Publisher Full Text

115. F Kammouni W, Wood H, Saleh A, et al:: Rabies virus phosphoprotein interacts with mitochondrial Complex I and induces mitochondrial dysfunction and oxidative stress. J Neurovirol. 2015; 21(4): 370-82. PubMed Abstract | Publisher Full Text | F1000 Recommendation 


\section{Open Peer Review}

\section{Current Peer Review Status:}

\section{Editorial Note on the Review Process}

Faculty Reviews are review articles written by the prestigious Members of Faculty Opinions. The articles are commissioned and peer reviewed before publication to ensure that the final, published version is comprehensive and accessible. The reviewers who approved the final version are listed with their names and affiliations.

\section{The reviewers who approved this article are:}

\section{Version 1}

\section{James Childs}

Yale School of Public Health, New Haven, CT, USA

Competing Interests: No competing interests were disclosed.

\section{Nicholas Johnson}

Animal and Plant Health Agency, Surrey, Surrey, UK

Competing Interests: No competing interests were disclosed.

The benefits of publishing with F1000Research:

- Your article is published within days, with no editorial bias

- You can publish traditional articles, null/negative results, case reports, data notes and more

- The peer review process is transparent and collaborative

- Your article is indexed in PubMed after passing peer review

- Dedicated customer support at every stage

For pre-submission enquiries, contact research@f1000.com 